\title{
Surgical and molecular pathology of pancreatic neoplasms
}

\author{
Wenzel M. Hackeng ${ }^{1}$, Ralph H. Hruban², G. Johan A. Offerhaus ${ }^{1}$ and Lodewijk A. A. Brosens ${ }^{1 *}$
}

\begin{abstract}
Background: Histologic characteristics have proven to be very useful for classifying different types of tumors of the pancreas. As a result, the major tumor types in the pancreas have long been classified based on their microscopic appearance.

Main body: Recent advances in whole exome sequencing, gene expression profiling, and knowledge of tumorigenic pathways have deepened our understanding of the underlying biology of pancreatic neoplasia. These advances have not only confirmed the traditional histologic classification system, but also opened new doors to early diagnosis and targeted treatment.

Conclusion: This review discusses the histopathology, genetic and epigenetic alterations and potential treatment targets of the five major malignant pancreatic tumors - pancreatic ductal adenocarcinoma, pancreatic neuroendocrine tumor, solid-pseudopapillary neoplasm, acinar cell carcinoma and pancreatoblastoma.

Keywords: Pancreas, Pancreatic cancer, Acinar cell carcinoma, Pancreatic neuroendocrine tumor, Solid-pseudopapillary neoplasm, Genetics, Histology, Methylation, microRNA, Sequencing
\end{abstract}

\section{Background}

Malignant neoplasms of the pancreas are currently classified based on the cellular direction of differentiation (ductal, acinar or neuroendocrine) of the neoplastic cells, combined with the macroscopic appearance (solid or cystic) of the tumors. Pancreatic ductal adenocarcinoma comprises about $90 \%$ of all malignant pancreatic neoplasms. Of all other malignant pancreatic neoplasms (pancreatic neuroendocrine tumors, solid-pseudopapillary neoplasm, acinar cell carcinoma and pancreatoblastoma), neuroendocrine tumors are the most common, comprising approximately $5 \%$ of malignant pancreatic tumors (Table 1).

Recent genetic and epigenetic characterization of these histologically distinct pancreatic tumors has increased our understanding of common genetic signatures, and has also identified tumor specific genetic alterations (Table 2). In addition to serving as diagnostic tools, some genetic alterations can be exploited as targets for therapy, opening avenues for new treatments. In this review, histology, genetics and epigenetics of malignant

\footnotetext{
*Correspondence: l.a.a.brosens@umcutrecht.nl

'Department of Pathology, University Medical Center Utrecht, Heidelberglaan 100, 3584 CX Utrecht, The Netherlands

Full list of author information is available at the end of the article
}

pancreatic tumors and potential targets for treatment are discussed.

\section{Pancreatic ductal adenocarcinoma}

Infiltrating ductal adenocarcinoma, also known as pancreatic ductal adenocarcinoma (PDAC), accounts for $90 \%$ of all malignant pancreatic neoplasms and occurs at a mean age of 66 years [1]. PDAC has a very poor prognosis with an overall 5 -year survival of only $7 \%$ [2]. At diagnosis, the majority of patients are inoperable due to locally advanced or metastatic disease. The median survival for patients with metastatic disease is less than a year [3]. Moreover, by the year 2030 pancreatic cancer is predicted to become the second leading cause of cancer-related death in the U.S. [4]. In view of the increasing incidence and the virtually unchanged poor prognosis of PDAC both new therapies for established pancreatic cancer as well as methods for prevention and early detection are desperately needed.

\section{Gross and microscopic findings}

PDACs are characteristically firm, ill-defined white-yellow masses (Fig. 1a). The pancreatic parenchyma upstream from PDACs is usually atrophic and the main pancreatic duct can be dilated. Microscopically, PDAC is composed 
Table 1 Differential diagnosis of malignant pancreatic neoplasms. Overview of pancreatic neoplasms with their relative prevalence, direction of differentiation, macroscopic and microscopic appearance, and immunohistochemical markers

\begin{tabular}{|c|c|c|c|c|c|c|c|}
\hline & $\begin{array}{l}\text { Prevalence }(\% \text { of } \\
\text { all malignant } \\
\text { pancreatic } \\
\text { tumors) }\end{array}$ & $\begin{array}{l}\text { Mean Age } \\
\text { (SD) in } \\
\text { years }\end{array}$ & $\begin{array}{l}\text { Sex } \\
\text { predominance }\end{array}$ & $\begin{array}{l}\text { Direction of } \\
\text { differentiation } \\
\text { Ductal/acinar/ } \\
\text { endocrine }\end{array}$ & $\begin{array}{l}\text { Gross: Solid/ } \\
\text { solid and } \\
\text { cystic/cystic }\end{array}$ & Microscopic & Immunohistochemical \\
\hline $\begin{array}{l}\text { Pancreatic ductal } \\
\text { adenocarcinoma }\end{array}$ & $90 \%$ & $66(11)$ & Male (3:2) & Ductal & Solid & $\begin{array}{l}\text { - Glandular and ductal structures } \\
\text { - Abundant desmoplastic stroma } \\
\text { - Eosinophilic to clear cytoplasm } \\
\text { and enlarged pleomorphic } \\
\text { nuclei } \\
\text { - Perineural, lymphatic and blood } \\
\text { vessel invasion }\end{array}$ & $\begin{array}{l}\text { Aberrant TP53 expression, SMAD4 loss, } \\
\text { expression of MUC1, MUC3, MUC4, MUC5AC, CA19-9 }\end{array}$ \\
\hline $\begin{array}{l}\text { Pancreatic } \\
\text { neuroendocrine } \\
\text { tumor/carcinoma }\end{array}$ & $5 \%$ & $58(15)$ & Male $(3: 2)$ & Endocrine & $\begin{array}{l}\text { Solid, } \\
\text { sometimes } \\
\text { cystic } \\
\text { degeneration }\end{array}$ & $\begin{array}{l}\text { - Nested or trabecular growth } \\
\text { pattern } \\
\text { - Granular amphophilic to } \\
\text { eosinophilic cytoplasm } \\
\text { - "Salt and pepper" chromatin }\end{array}$ & $\begin{array}{l}\text { Expression of synaptophysin and chromogranin, peptide } \\
\text { hormones (e.g. insulin and glucagon), aberrant nuclear } \\
\text { TP53 expression in PanNECs }\end{array}$ \\
\hline $\begin{array}{l}\text { Solid- } \\
\text { pseudopapillary } \\
\text { neoplasm }\end{array}$ & $1-2 \%$ & $29(14)$ & Female $(9: 1)$ & Uncertain & $\begin{array}{l}\text { Solid and } \\
\text { cystic }\end{array}$ & $\begin{array}{l}\text { - Poorly cohesive uniform cells } \\
\text { - Extensive degenerative } \\
\text { changes. } \\
\text { - Eosinophilic or clear vacuolated } \\
\text { cytoplasm Round to oval nuclei, } \\
\text { often grooved or indented. } \\
\text { - Eosinophilic globules and } \\
\text { foamy macrophages }\end{array}$ & $\begin{array}{l}\text { Abnormal nuclear labeling for } \beta \text {-catenin, expression of CD10, } \\
\text { paranuclear dot-like CD99 labeling or lymphoid enhancer- } \\
\text { binding factor } 1 \text { (LEF1). Loss of membranous E-cadherin }\end{array}$ \\
\hline $\begin{array}{l}\text { Acinar cell } \\
\text { Carcinoma }\end{array}$ & $1-2 \%$ & $\begin{array}{l}56(15) \\
6 \% \\
\text { between } 8 \\
\text { and } 15\end{array}$ & Male $(2: 1)$ & Acinar & $\begin{array}{l}\text { Solid, } \\
\text { sometimes } \\
\text { cystic } \\
\text { degeneration }\end{array}$ & $\begin{array}{l}\text { - Enlarged uniform nuclei with } \\
\text { prominent nucleoli } \\
\text { - Finely granular eosinophilic } \\
\text { cytoplasm. } \\
\text { - Small acinar units or sheets }\end{array}$ & $\begin{array}{l}\text { BCL10, expression of pancreatic exocrine enzymes: } \\
\text { trypsin, chymotrypsin, lipase }\end{array}$ \\
\hline Pancreatoblastoma & $<1 \%$ & $\begin{array}{l}5(2), \\
\text { second } \\
\text { peak } \\
\text { around } 40\end{array}$ & Slightly male & Acinar & $\begin{array}{l}\text { Solid, cystic } \\
\text { in BWS }^{\text {a }}\end{array}$ & $\begin{array}{l}\text { - Similar to ACC } \\
\text { - Squamoid nests required for } \\
\text { diagnosis } \\
\text { - Neuroendocrine or ductal } \\
\text { component. }\end{array}$ & $\begin{array}{l}\text { Expression of pancreatic exocrine enzymes, BCL10, } \\
\text { SMAD4 loss, Abnormal nuclear labeling for } \beta \text {-catenin }\end{array}$ \\
\hline
\end{tabular}


Table 2 Overview of pancreatic neoplasms with their key genetic alterations and several epigenetic alterations discussed in this review

\begin{tabular}{|c|c|c|c|c|}
\hline & $\begin{array}{l}\text { Average } \\
\text { number of } \\
\text { somatic } \\
\text { mutations }\end{array}$ & Major genes involved & Methylation & $\begin{array}{l}\text { MiRNA tumor expression } \\
\text { compared to normal pancreatic } \\
\text { tissue }\end{array}$ \\
\hline \multirow[t]{2}{*}{$\begin{array}{l}\text { Pancreatic ductal } \\
\text { adenocarcinoma }\end{array}$} & \multirow[t]{2}{*}{$20-80$} & \multirow{2}{*}{$\begin{array}{l}\text { KRAS, CDNK2A, SMAD4, TP53, } \\
\text { MLL3, TGFBR2, ATM, ARID1A, } \\
\text { ROBO2, KDM6A }\end{array}$} & \multirow[t]{2}{*}{$\begin{array}{l}\text { Loss of function through promotor } \\
\text { hypermethylation: CDNK } 2 A, h M L H 1 \text {, }\end{array}$} & $\begin{array}{l}\text { Upregulation: miR-21, 23a, 31, 100, } \\
143,155 \text {, and } 221\end{array}$ \\
\hline & & & & $\begin{array}{l}\text { Downregulation: miR-148a, } 217 \\
\text { and } 375\end{array}$ \\
\hline \multirow{2}{*}{$\begin{array}{l}\text { Pancreatic } \\
\text { Neuroendocrine } \\
\text { tumor/carcinoma }\end{array}$} & \multirow[t]{2}{*}{16} & \multirow[t]{2}{*}{$\begin{array}{l}\text { MEN1, ATRX, DAXX, TSC2, } \\
\text { PTEN }^{\prime \prime}, \text { Rb, TP53* }\end{array}$} & \multirow{2}{*}{$\begin{array}{l}\text { Hypomethylation of LINE1 and } \\
\text { hypermethylation of RASSFIA promoting } \\
\text { the accumulation of } \beta \text {-catenin }\end{array}$} & $\begin{array}{l}\text { Upregulation: miR-193b, } 103 \text { and } \\
107\end{array}$ \\
\hline & & & & Downregulation: miR-155 \\
\hline $\begin{array}{l}\text { Solid- } \\
\text { pseudopapillary } \\
\text { neoplasm }\end{array}$ & 3 & CTNNB1 & u & $\begin{array}{l}\text { MiRNAs possibly upregulating the } \\
\text { Wht, Hedgehog, and Androgen } \\
\text { receptor pathway }\end{array}$ \\
\hline \multirow[t]{2}{*}{$\begin{array}{l}\text { Acinar cell } \\
\text { carcinoma }\end{array}$} & \multirow[t]{2}{*}{131} & \multirow{2}{*}{$\begin{array}{l}\text { SMAD4, JAK1, BRAF, RB1, TP53, } \\
\text { APC, ARID1A, GNAS, MLL3, } \\
\text { PTEN }\end{array}$} & \multirow[t]{2}{*}{$\begin{array}{l}\text { Hypermethylation of RASSF1, } \\
M L H 1 \text { and } A P C\end{array}$} & $\begin{array}{l}\text { Upregulation: miR-17, 20, 21, 92-1, } \\
103,107\end{array}$ \\
\hline & & & & Downregulation: miR-155 \\
\hline Pancreatoblastoma & 18 & $\begin{array}{l}\text { Loss of chromosome } 11 \mathrm{p} \text {, } \\
\text { CTNNB1 }\end{array}$ & Hypermethylation of RASSFIA & u \\
\hline
\end{tabular}

$u$ unknown. ${ }^{*}$ MEN1, ATRX, DAXX, TSC2 and PTEN mutations are found in well-differentiated PanNET but not in PanNEC. ${ }^{*}$ Rb and TP53 mutations are present in PanNEC, but not in well-differentiated PanNET
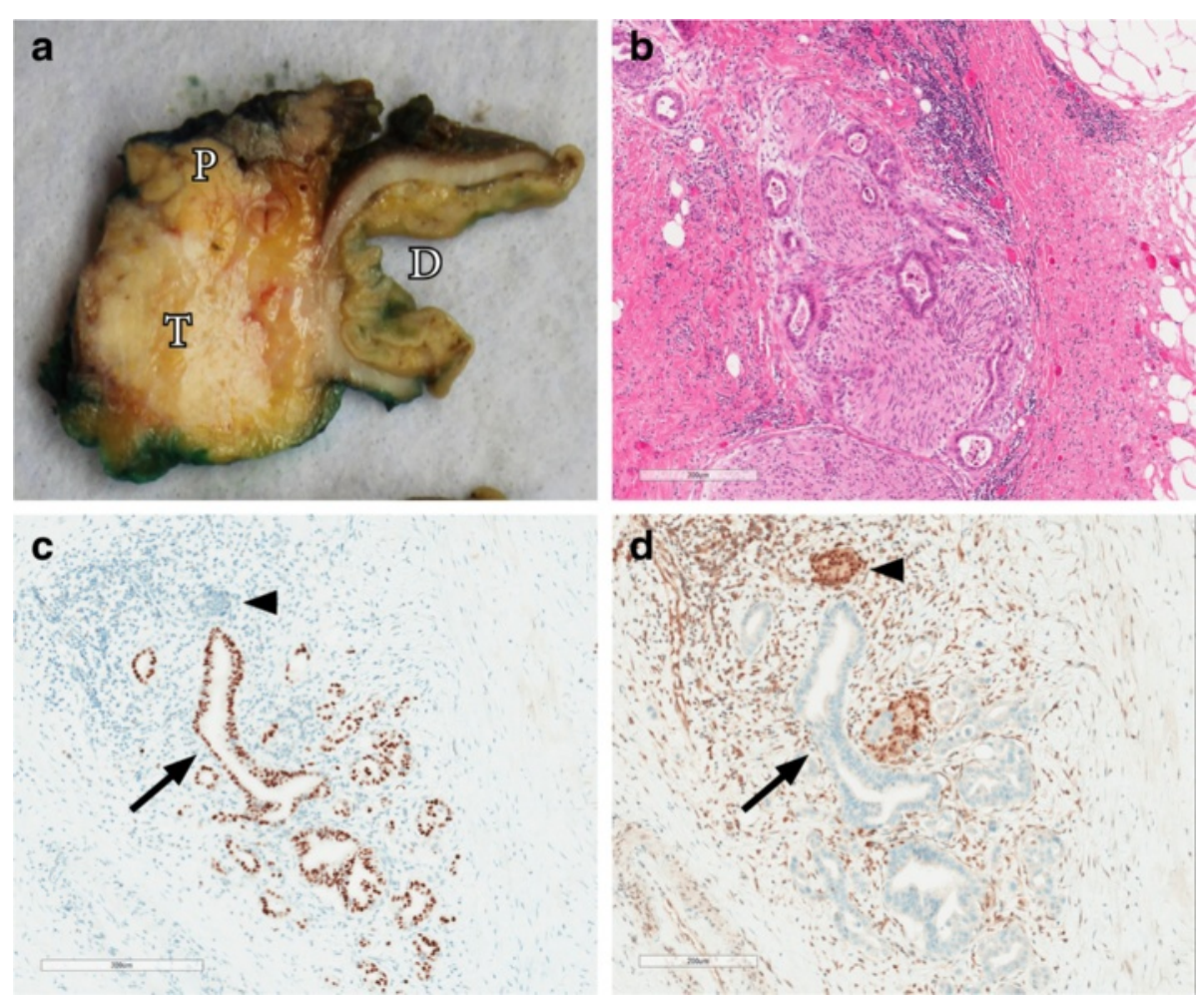

Fig. 1 a Macroscopic appearance of a pancreatic ductal adenocarcinoma showing a poorly demarcated firm white tumor in the pancreatic parenchyma (T Tumor, P pancreatic parenchyma, D duodenum). b Perineural invasion of a pancreatic ductal adenocarcinoma. c Positive TP53 immunohistochemistry in pancreatic ductal adenocarcinoma indicative of TP53 gene mutation. Arrow, malignant ductal structure; arrowhead, normal pancreatic duct. $\mathbf{d}$ Loss of SMAD4 immunohistochemistry in pancreatic ductal adenocarcinoma indicating mutation of the SMAD4 gene. Arrow, malignant ductal structure; arrowhead, normal pancreatic duct 
of haphazardly arranged infiltrating glandular and ductal structures typically surrounded by abundant desmoplastic stroma. The cells have eosinophilic to clear cytoplasm and usually enlarged pleomorphic nuclei. Poorly differentiated ductal adenocarcinomas have more irregular and smaller glands and significant pleomorphism. Perineural, lymphatic and blood vessel invasion are frequently present (Fig. 1b). The neoplastic cells in areas of venous invasion can be so well-differentiated that they mimic non-invasive precursor lesions (pancreatic intraepithelial neoplasia). Immunohistochemically, there is no definite marker to distinguish PDAC from non-neoplastic ductal structures, although aberrant TP53 expression or SMAD4 loss support the diagnosis of PDAC over reactive glands (Fig. 1c and d) $[5,6]$. Several types of mucin (MUC1, MUC3, MUC4, MUC5AC) and glycoprotein tumor antigens such as CA19-9 can be expressed in PDAC [7-9]. The main microscopic differential diagnosis consists of PDAC precursor lesions, other malignant pancreatic tumors (Table 1), pancreatitis and adenocarcinoma metastasis.

PDAC develops from precursor lesions that can be either microscopic (pancreatic intraductal neoplasia, PanIN) or macroscopic cystic precursor lesions (intraductal papillary mucinous neoplasm, IPMN; mucinous cystic neoplasm, MCN) (Fig. 2). IPMN and MCN are often found as incidental finding on imaging. PanIN arises in microscopic ducts; IPMN arises within the main- or branch-ducts. MCN usually does not communicate with the ductal system. Microscopically, all precursors show flat or papillary mucin-producing neoplastic epithelium, with varying degrees of dysplasia and directions of differentiation. Stepwise accumulation of (epi)genetic alterations drives neoplastic progression and eventually development of malignant invasive carcinoma, analogous to the PanIN progression model as depicted in Fig. 3 and discussed below [10, 11].

\section{Genetic signature: familial PDAC}

Approximately $10 \%$ of pancreatic cancers appear to have an inherited component. Overall, sporadic and familial PDAC share the same driver mutations (KRAS, CDKN2A, TP53 and SMAD4) [12], but some of these cases are caused by inherited germline genetic alterations in genes that significantly increase the risk of pancreatic cancer (Table 3). These genes include BRCA2, BRCA1, PALB2, p16/CDKN2A, ATM, STK11, PRSS1, and the DNA mismatch repair genes (such as MLH1 and MSH2) [13-17]. In addition, a number of other candidate genes, such as BUB1B, CPA1, FANCC and FANCG, have been described [12]. These germline alterations are critical to understand because the risk is significant and at-risk patients can be enrolled in screening and early detection protocols for pancreatic and extra-pancreatic tumors [18]. In addition, some patients with specific genetic alterations can be prioritized for specific therapies. For example, some tumors
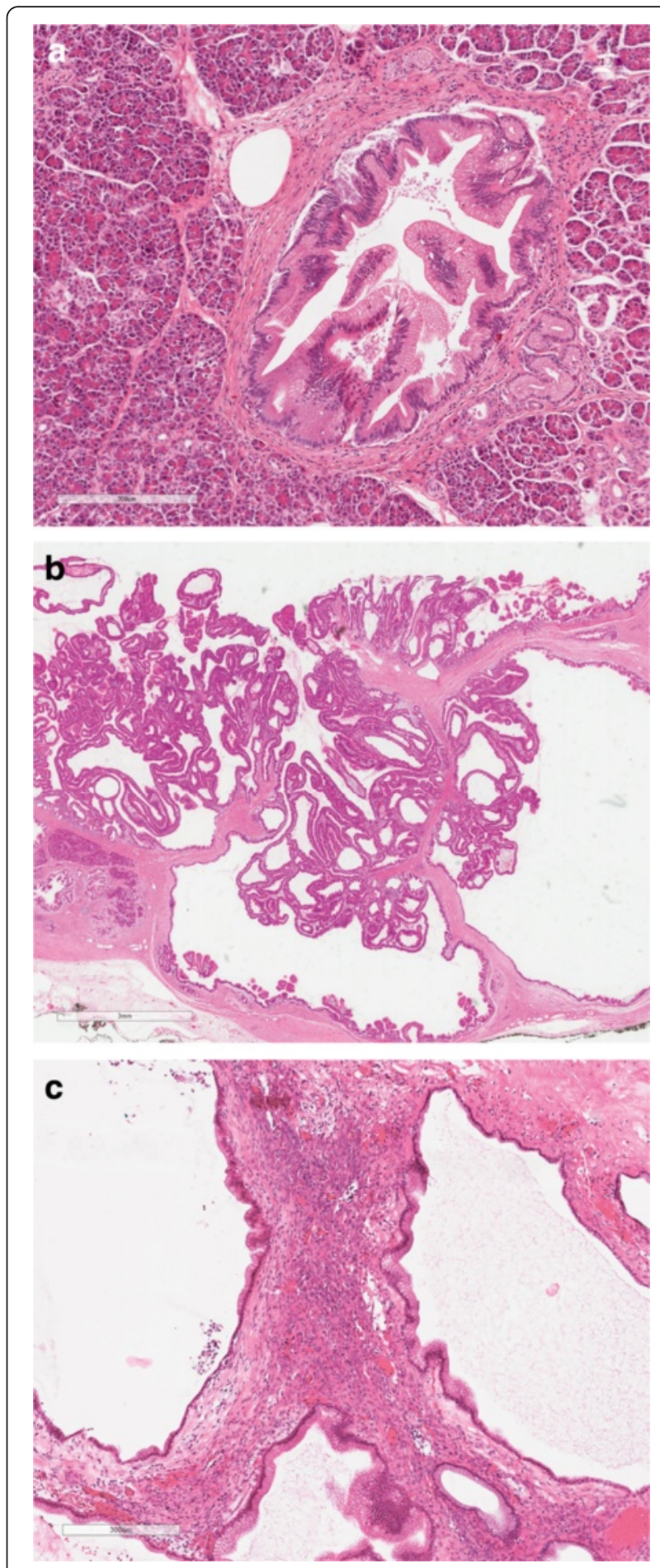

Fig. 2 a Low-grade pancreatic intraepithelial neoplasia (PanlN) showing micro-papillary epithelium with mild to moderate cytological atypia. b Intraductal papillary mucinous neoplasm (IPMN), gastric-foveolar type with low-grade dysplasia. c Mucinous cystic neoplasm (MCN) showing gastric-foveolar type epithelium with lowgrade dysplasia, surrounded by ovarian-type stroma 


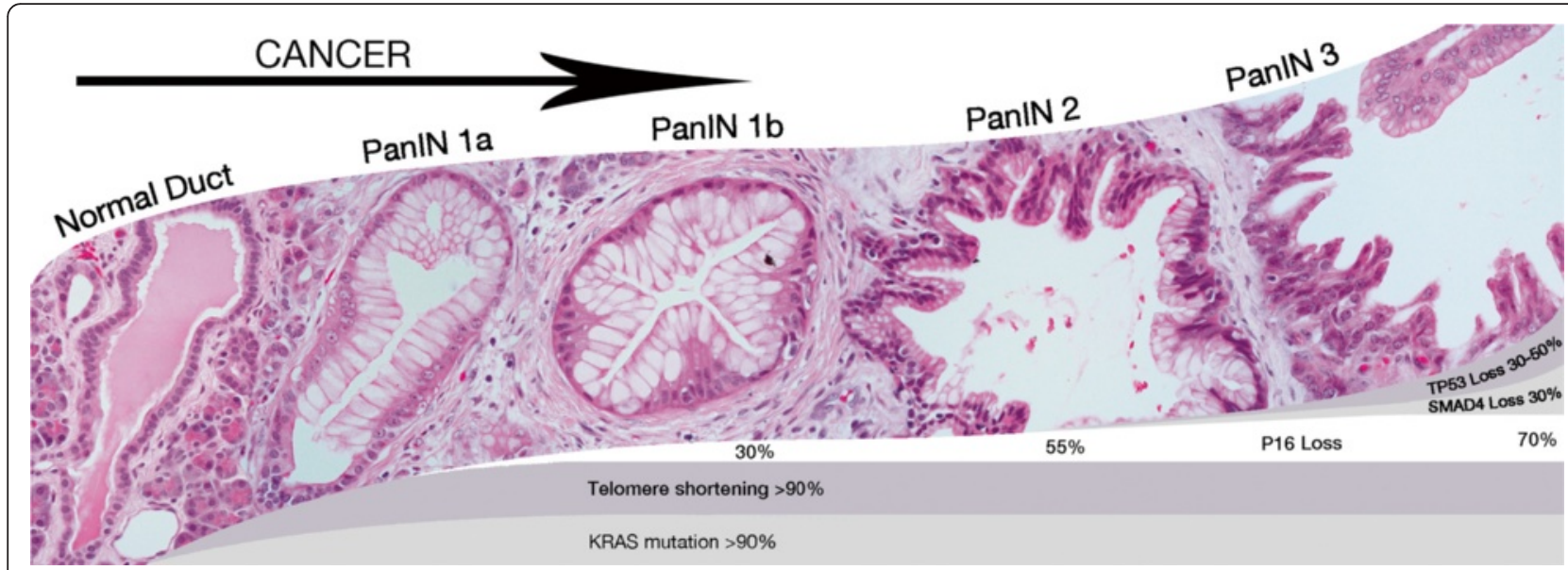

Fig. 3 Pancreatic cancer develops from the well-defined precursor lesions pancreatic intraepithelial neoplasia, intraductal papillary mucinous neoplasm and mucinous cystic neoplasm. The PanIN progression model shown here shows that accumulation of genetic and epigenetic alterations drives neoplastic progression in these precursor lesions from low-grade dysplasia (PanIN 1 and PanIN 2) to high-grade dysplasia (PanIN 3) to eventually an invasive pancreatic adenocarcinoma

characterized by microsatellite instability due to a DNA mismatch repair gene defect are exquisitely responsive to immunotherapies, and some tumors with $B R C A$ or PALB2 gene mutation are sensitive to poly ADP ribose polymerase (PARP)-inhibitors [19-21].

In addition to these low prevalence but high penetrance genes, there are a number of more common lower penetrance genes that increase the risk of pancreatic cancer only slightly. A number of these, including $\mathrm{ABO}$ blood group type, have been identified in genome wide association studies (GWAS) [22-24].

Table 3 Overview of germline genetic alterations with welldefined pancreatic cancer risk and genes that have been associated with familial PDAC

\begin{tabular}{ll}
\hline Gene (syndrome) & $\begin{array}{l}\text { RR (Cumulative } \\
\text { lifetime risk (\%) } \\
\text { by age 70) }\end{array}$ \\
\hline STK11/LKB1 (Peutz-Jeghers syndrome) & $132(36)$ \\
PRSS1/SPINK1 (hereditary pancreatitis) & $50-80(40)$ \\
CDKN2A (FAMMM) & $13-47(17)$ \\
BRCA1/BRCA2 (HBOC) & $3.5-10(3-8)$ \\
MLH1, MSH2, MSH6, PMS2 (Lynch syndrome) & $8.6(<5)$ \\
CFTR (Cystic fibrosis) & $5(<5)$ \\
FDR with PC & $2-3(2)$ \\
FDRs with PC & $6(8-12)$ \\
POSSible role in FPC: & Unknown \\
ATM, TET2, DNMT3A, POLN, POLQ, ASXL1, PALB2, FANCG, \\
BUB1B, ESCO2, FANCC, FANCM, MSH4, RAD54L
\end{tabular}

$R R$ relative risk, $F D R$ first degree relative, FAMMM familial atypical multiple mole melanoma, $H B O C$ hereditary breast and ovarian cancer syndrome, FAP familial adenomatous polyposis, $P C$ pancreatic cancer, $F P C$ familial pancreatic cancer. Adapted from Ghiorzo et al. and Roberts et al. [12, 151]

\section{Genetic signature: sporadic PDAC}

The somatic alterations present in PDAC are now well characterized thanks to several large whole-exome and whole-genome sequencing studies [21, 25-27]. On average PDACs have 50-80 exomic non-silent mutations [21, 25-27]. In addition, extensive larger structural variations including intra-chromosomal rearrangements, deletions and amplifications are common in PDAC [21, 28].

Point mutation of the oncogene KRAS is seen in almost all early pancreatic cancer precursor lesions and in PDACs. Subsequent mutations that drive neoplastic progression in PanIN lesions are usually in the tumor suppressor genes CDKN2A, TP53 and SMAD4 (Fig. 3) $[21,25,26]$. Further accumulation of genetic and epigenetic alterations drives neoplastic progression in these precursor lesions, eventually leading to an invasive pancreatic adenocarcinoma [10]. Less commonly mutated genes in PDAC include MLL3, TGFBR2, ATM, ARID1A, ROBO2 and KDM6A [21, 25-27]. Of note, mutations in chromatin-regulating genes $(M L L$, MLL2, MLL3 and ARID1A) have been associated with improved survival, and loss of SMAD4 with poorer survival [29, 30]. Many mutations found by whole exome sequencing are reported in a very low percentage of tumors, and therefor categorized as passengers in tumorigenesis. Of note the recently proposed "mini driver" model hypothesizes that several passengers might have relatively weak tumor-promoting effects but together might substitute for a major-driver [31]. More research is needed to address the exact role of most of these less prevalent mutations in tumorigenesis.

Importantly - despite the diversity of genes targeted - the genetic alterations in PDAC appear to selectively target core signaling pathways, including Wnt/Notch signaling, 
TGF- $\beta$ signaling, and DNA damage control [26]. Despite the genetic heterogeneity of PDAC, targeting one or more of these pathways may be more effective than targeting a specific genetic alteration. For example, Waddell et al. recently correlated deleterious mutations in BRCA1 and $B R C A 2$ with unstable genetic signatures ( $>200$ structural variations). In their study, 4 out of 5 patients with defective DNA damage control responded to treatment with a platinum containing regimen. Also PARP inhibitors have been reported to be effective in BRCA mutated tumors [21]. These findings illustrate how knowledge of rare mutations in known pathways can be used to guide treatment. A number of clinical trials targeting specific pathways and mutations are being conducted on patients with PDAC and other human cancers. Potential targets for therapeutic intervention are seen in over a third of PDACs (up to $97 \%$ when trials related to KRAS and TP53 are included) [29]. Future personalized treatment might thus drastically change outcome of this disease.

Studies of the clonal evolution of genetic changes in pancreatic cancer and metastases by Yachida et al. suggest that it takes almost 12 years from the initiating mutation in the pancreas until development of an invasive PDAC [32]. This suggests a wide window of opportunity for the early detection of pancreatic cancer. The genetic alterations present in pancreatic cancer and its noninvasive precursors can be shed into the blood and into the pancreatic duct system. This suggests the possibility of gene-based early detection tests. Indeed, mutant KRAS shed from invasive pancreatic cancer can be detected in the plasma, and mutations present in noninvasive cystic precursor lesions, such as IPMNs and MCNs can be detected in cyst fluid aspirated at the time of endoscopic ultrasound (EUS), as well as in secretin stimulated pancreatic juice collected from the duodenum $[33,34]$.

\section{Epigenetic alterations}

A number of genes are aberrantly methylated in pancreatic cancer [35-41]. For example, integrated methylation and gene-expression meta-analysis have identified a number of genes (MUC4, SERPINB5, CLDN4, SFN, TFF1, S100P, S100A4, MMP1, MMP7, MSLN, PSCA, ID1, MST1R, NBL1, PHLDA2, PLAT, PLAUR, IL8, SPP1, ARHGDIB, $N Q O 1$, and ITGB4) that are significantly upregulated in PDAC, likely caused by promoter hypomethylation [36, 42, 43]. Some of the genes targeted by changes in methylation are clearly cancer-causing, such as the well-known tumor suppressor gene $C D N K 2 A$ and the DNA repair gene $h M L H 1$, which show loss of function through promoter hypermethylation silencing [40, 44-46].

These epigenetic changes are not only functionally important, but can also be used as markers of disease and early detection. For example, DNA methylation alterations in the pancreatic juice are a possible approach to the diagnosis of pancreatic cancer [47].

\section{MicroRNA}

Post-transcriptional regulation or silencing of gene expression occurs mostly by non-coding RNAs. The most studied non-coding RNAs are microRNAs (miRs), which are small single stranded RNA molecules that regulate mRNA by full or partial complementarity. Deregulated miRs can give information on transcriptional regulation and may serve as biomarkers for survival and early detection [48-50].

Recently a large meta-analysis looked at the miR expression profiles of 538 PDACs. A statistically significant miR meta-signature with upregulation of miR-21, 23a, 31, 100, 143, 155, and 221 and downregulation of miR-148a, 217 and 375 was found in PDAC. Furthermore, in a cohort of 70 patients, the high expression of miR-21, miR-31 and the low expression of miR-375 in their PDACs was found to be an independent prognostic marker for poor overallsurvival [50]. Interestingly, in stool from patients with PDAC, significantly higher miR-21 and miR-155 and lower miR-216 levels have been found compared to normal controls [51]. Other studies with "disease free survival" and "overall survival" as outcome measures also found an important role for high levels of miR-21 in predicting prognosis, along with high miR-155, high miR-203, and low miR-34a [49].

MiR-21 is thus an important candidate for diagnostic and prognostic purposes, although it cannot be used to differentiate between PDAC and precursor lesions such as intraductal papillary mucinous neoplasms (IPMN) or malignancy in other organs [52, 53]. MiR-21 has approximately 180 target messenger RNAs (mRNA) [54]. Interestingly several of these targets are tumor suppressors and negative regulators of the Ras/MEK/ERK pathway. An in vivo study with a murine non-small cell lung carcinoma model confirmed upregulation of miR-21 with RAS activation, and downregulation of several negative RAS regulators and tumor suppressors including SPRY1, SPRY2, BTG2, and PDCD4 [54]. In vitro studies have reported several other miR-21 affected tumor suppressor mRNAs, including PTEN [55]. Deletion of miR-21 has also been shown to repress tumor formation in KRAS mutated mice and makes in vitro cells more sensitive for chemotherapy, possibly by repression of the AKT pathway through $\mathrm{p} 85 \alpha$ inhibition [56]. MiR-21 may thus be potentially interesting as pharmacological target as well.

Research on miRs is booming, and many recent studies have found other and new miRs not reported in the meta-reviews, also to be excellent prognostic markers for PDAC [57-60]. Other forms of non-coding RNA like long non-coding RNA (lncRNA), small nucleolar-derived 
RNA (sdRNA) and piwi-interacting RNA (piRNA) are also differentially altered in PDAC [61].

\section{Changes in gene expression}

Several studies have tried to classify PDAC into clinically meaningful subgroups based on gene expression profiles. Collisson et al. clustered 3 distinct subtypes of PDAC (classical, quasimesenchymal and exocrine-like) with different responses to treatment and different patient prognosis [62]. Recently Moffitt et al. used blinded digital separation of PDAC gene expression microarray data to cluster primary carcinoma, metastasis, and normal samples [63]. They found that the groups described by Collisson et al. did not hold predictive power in their samples. Instead they identified two tumor subtypes: "classical" which had great overlap with the classical group of Collison et al., and basal-like which had a worse outcome and was molecularly similar to basal tumors in the bladder. Furthermore, as they could digitally separate tumor and stromal expression, they defined "normal" and "activated" stromal subtypes, which they reported to be independent prognostic factors [63]. Currently, there is no well-established clinically meaningful subclassification of PDAC.

Differentially upregulated genes by mRNA can result in upregulation of proteins, which - just like DNA, miRNA and mRNA - can be used as potential diagnostic biomarkers of malignancy in pancreatic juice and blood [64]. Furthermore, specific mutated proteins such as mutant Ras can be distinguished from wild-type Ras by mass spectrometry in tissue and pancreatic juice, which might be even more useful for early diagnosis of PDAC and its precursors [65]. Other highly expressed proteins including mesothelin are potentially targetable with immunotherapy [66]. Mutant proteins can also give rise to aberrant epitopes on tumor MHC receptors, which then can specifically be targeted by adoptive T-cell therapy as elegantly demonstrated in other human cancers [67].

\section{Stroma and the tumor microenvironment}

In addition to genetic alterations, the tumor microenvironment and changes in epigenetic regulation play important roles in promoting or suppressing PDAC growth $[68,69]$ and stromal expression profile has shown prognostic significance [63]. Also, by overexpression of hyaluronic acid and collagens, the extracellular matrix can cause a high interstitial fluid pressure, causing compression of blood vessels and therefor hindering passive transport processes of chemotherapeutics. Targeting these stromal factors might improve therapeutic response [70].

PDAC and its microenvironment are also marked by distinct immune cell populations along its path of tumorigenesis, creating an immunosuppressive environment that shields tumor cells from detection and renders them resistant to immune-based therapies. Regulatory T-cells (T-reg) seem to play a role from the earliest stage of precursor disease potentially undermining anti-tumor effector T-cell activity; high intratumor T-reg/CD4 ${ }^{+} \mathrm{T}$-cell ratio is a prognostic factor for worse survival. Therapeutically targeting of T-regs in malignancy is currently under investigation [70].

\section{Pancreatic neuroendocrine tumors}

Pancreatic neuroendocrine tumors (PanNET) are the second most common malignant tumor of the pancreas [6]. PanNETs occur mostly in elderly patients, with a mean age of 58 years [71]. Although prognosis of PanNET is better than PDAC, it is still poor with an average overall 5 year survival of only $42 \%$ [72]. Functional PanNETs are well known for their classic clinical presentations including Whipple's triad (insulinoma) and Zollinger-Ellison syndrome (gastrinoma), in which hypersecretion of pancreatic or non-pancreatic hormones have systemic effects. When no systemic effects of hormone production are seen, PanNETs are by definition classified as nonfunctional [5].

A number of TNM classification systems with prognostic value for PanNET patients have been developed by the WHO2010 [World Health Organization], ENETs [European Neuroendocrine Tumor Society] and AJCC [American Joint Committee on Cancer] [73]. Although it is at present not completely established which system should be preferred, a recent study suggests that the ENETs TNM classification was superior to the AJCC/ WHO2010 classification/grading System and more accurate [74].

\section{Gross and microscopic findings}

PanNETs are usually soft, sometimes red or white, welldemarcated lesions (Fig. 4a). Microscopically the neoplastic cells have a nested or trabecular growth pattern. At higher magnification, the neoplastic cells have a distinct neuroendocrine morphology, with a granular amphophilic to eosinophilic cytoplasm and the typical coarsely clumped "salt and pepper" chromatin (Fig. 4b). The mitotic rate and percentage of Ki67 positive cells are used for grading. The well-differentiated PanNETs can be either grade 1 ( $<2$ mitoses per $10 \mathrm{HPF}$; Ki-67 labeling index $<2 \%)$ or grade 2, (2-20 mitoses per $10 \mathrm{HPF}$; Ki-67 labeling index $3-20 \%$ ). If mitotic count is $>20$ mitoses per 10 HPF or Ki-67 index is $>20 \%$, the neoplasm is classified as a grade 3 neuroendocrine tumor or neuroendocrine carcinoma (PanNEC). Histologically PanNECs can have one of two appearances. Those with a Ki-67<50 \% can look similar to the well-differentiated PanNETs, only they have a high proliferation rate [75]. This group is somewhat more aggressive than grade 2 PanNETs but not as rapidly progressive as the PanNECs with a Ki67 $>50 \%$. PanNECs 

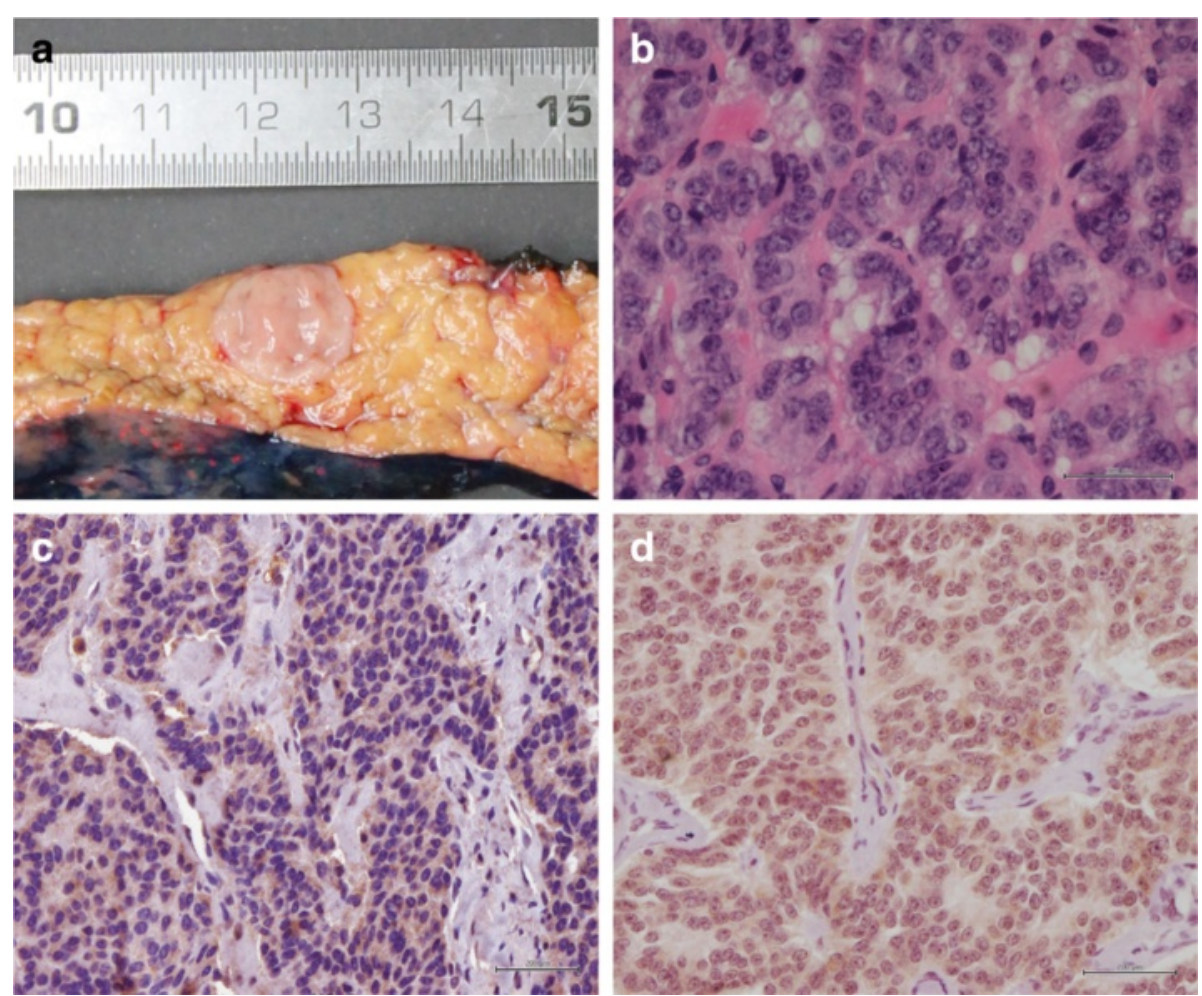

Fig. 4 a Macroscopic appearance of pancreatic neuroendocrine tumor showing a well-demarcated pinkish tumor surrounded by normal pancreatic parenchyma. b Pancreatic neuroendocrine tumor, detail showing typical salt and pepper chromatin. $\mathbf{c}$ Loss of Menin expression in pancreatic neuroendocrine tumor indicative of MEN1 gene inactivation. $\mathbf{d}$ Retained Menin expression in pancreatic neuroendocrine tumor with a wildtype MEN1 gene

with a very high proliferation rate $(>50 \%)$ can have a small cell carcinoma or large cell carcinoma appearance with markedly pleomorphic typical neuroendocrine cells that are tightly packed in nests or form diffuse irregular sheets [5]. Necrosis is often seen.

Immunohistochemical expression of neuroendocrine markers synaptophysin and chromogranin A is seen in the majority of PanNETs [76], and peptide hormones (e.g. insulin and glucagon) can also confirm neuroendocrine differentiation. Large cell PanNECs typically express neuroendocrine markers, but small cell PanNECs may not. Both large and small cell PanNECs are typically negative for peptide hormones [77]. Aberrant nuclear TP53 expression is commonly found in PanNECs but is never seen in PanNETs [78]. The main microscopic differential diagnosis consists of acinar cell carcinoma (Fig. 7), pancreatoblastoma, mixed neuroendocrine tumors, and dedifferentiated PDAC (Table 1).

\section{Genetic signature: familial PanNET}

The vast majority (90\%) of PanNETs occur sporadically, but some occur in the setting of associated familial syndromes including multiple endocrine neoplasia type 1 (MEN1), von Hippel-Lindau syndrome (VHL), neurofibromatosis type 1 (NF1), tuberous sclerosis complex (TSC) and the recently discovered glucagon cell adenomatosis (GCA) [5, 79]. Studies of PanNETs occurring in patients with an underlying genetic predisposition have provided important insight into the genes involved in tumorigenesis of PanNETs. Tumorigenesis in these syndromes follow a hyperplasia-neoplasia sequence in which hyperplastic nodules transform over time into frank neoplasms [79-81]. It is assumed that sporadic cases PanNETs develop through a similar hyperplasia-neoplasia sequence. PanNECs are not associated with germline syndromes and are believed to follow a different pathway of tumorigenesis [78].

\section{Genetic signature: sporadic PanNET}

Whole exome and targeted sequencing of well differentiated PanNETs (grade 1 and 2) of patients without a familial syndrome showed an average of only 16 nonsynonymous mutations per tumor [82]. Somatic mutations of the MEN1 gene were found in $45 \%$ of these sporadic PanNETs [82]. Others have previously reported loss of heterozygosity at the MEN1 locus in 20-45\% of sporadic PanNETs [83, 84]. In addition to prevalent somatic MEN1 mutations, $45 \%$ of sporadic PanNETs harbored somatic inactivating mutations 
in ATRX or DAXX, and $15 \%$ had mutations in mTOR pathway genes (in which TSC1/2 functions) [82]. Remarkably, the alternative lengthening of telomeres (ALT) phenotype, a mechanism of telomerase independent telomere maintenance to overcome cell death, was found to correlated perfectly with loss of ATRX and DAXX [85-87]. Moreover, many gains and losses have been reported in sporadic PanNETs [88, 89]. VHL is deleted in $18 \%$ of sporadic PanNET, and recently allelic loss of PHLDA3 - a regulator of the mTOR pathway - was found in $70 \%$ of sporadic PanNETs [90, 91].

The genetic alterations in well-differentiated PanNETs (grades 1 and 2) have been compared to those in PanNEC (grade 3). Yachida et al. found that small and large cell PanNECs are genetically similar, but distinct from PanNETs [78]. In PanNECs, activating KRAS mutations ( 2 of 7) and inactivating mutations in TP53 (4 of 7) and RB1 (5 of 7) were seen. By contrast, none of these mutations were found in 11 well-differentiated PanNETs. Abnormal expression of the TP53 (95 \%) and RB1 (75\%) proteins was also frequently seen in PanNEC, but not in well-differentiated PanNETs. Furthermore, all PanNECs retained expression of ATRX and DAXX, while, as noted above, PanNETs showed loss of expression of ATRX and DAXX in $45 \%$ of cases (Table 4) [78].

As mentioned earlier, sporadic PanNETs likely develop through a similar hyperplasia-neoplasia sequence as familial PanNETs. MEN1 syndrome associated PanNETs show loss of the wild-type MEN1 allele in up to $100 \%$ of cases (compared to $19-44 \%$ in sporadic PanNETs). Loss of the wild-type MEN1 allele is also seen in microadenomas of MEN1 patients and is therefore an early event [83, 92-94]. Loss of Menin can be demonstrated by immunohistochemistry (Fig. $4 \mathrm{c}$ and d). In nonsyndromic patients, it is unclear which initiating events cause microadenomas to develop, also bearing in mind that not all sporadic PanNETs have MEN1 alterations.

$A T R X$ and DAXX mutations with ALT activation have been reported to correlate significantly with tumor size

Table 4 Mutations in pancreatic MEN1 syndrome associated microadenomas and PanNETs, sporadic PanNETs and PanNECs

\begin{tabular}{|c|c|c|c|c|c|c|}
\hline \multirow[t]{2}{*}{ Neoplasm } & \multicolumn{6}{|c|}{ Mutations } \\
\hline & MEN1 & $\begin{array}{l}\text { ATRX } \\
\text { DAXX }\end{array}$ & $\begin{array}{l}\text { mTOR } \\
\text { pathway }\end{array}$ & KRAS & TP53 & $R B 1$ \\
\hline $\begin{array}{l}\text { MEN1 syndrome } \\
\text { microadenomas }\end{array}$ & $\begin{array}{l}\text { Up to } \\
100 \%\end{array}$ & $0 \%$ & u & u & u & u \\
\hline $\begin{array}{l}\text { MEN-1 syndrome } \\
\text { tumors }\end{array}$ & $\begin{array}{l}\text { Up to } \\
100 \%\end{array}$ & $6 \%$ & u & u & u & u \\
\hline $\begin{array}{l}\text { G1/G2 Pancreatic } \\
\text { neuroendocrine tumors }\end{array}$ & $45 \%$ & $45 \%$ & $15 \%$ & $0 \%$ & $0 \%$ & $0 \%$ \\
\hline $\begin{array}{l}\text { G3 Pancreatic } \\
\text { neuroendocrine } \\
\text { carcinomas }\end{array}$ & u & $0 \%$ & u & $30 \%$ & $60 \%$ & $70 \%$ \\
\hline
\end{tabular}

and T-stage, and are thus considered a late event in tumor progression. In total $45 \%$ of PanNETs have alterations in one of both genes [86, 87]. Although less likely, it is not known if sporadic microadenomas have ATRX or $D A X X$ alterations.

In contrast to sporadic PanNETs, ATRX and DAXX alterations were only seen in $6 \%$ of PanNETs from MEN1 syndrome patients (but also as late event) and in $0 \%$ of microadenomas suggesting a less important role for these alterations in MEN1 syndrome tumor progression [95].

\section{Epigenetic alterations}

Few studies investigated epigenetic alterations in PanNETs. Hypomethylation in LINE-1 was reported in $20 \%$ of welldifferentiated PanNETs, and strongly correlated with poor prognosis and high stage [96]. Other studies found hypermethylation of the tumor suppressor gene RASSF1A in 75-80 \% of PanNETs with associated decreased protein expression of RASSF1A [97, 98]. Interestingly, the RASSF1 gene has six other transcriptional variants (B-G), of which RASSF1C was seen to be expressed 10 times higher in PanNET than in normal tissue [98]. An in vitro study found the balance between isoform $\mathrm{A}$ and $\mathrm{C}$ crucial for the expression of $\beta$-catenin, where silencing RASSF1A and expression of RASSF1C promotes the accumulation of $\beta$ catenin by inhibiting its $\mathrm{hTrCP}$ mediated proteasomal degradation [99], possibly sustaining Wnt signaling in PanNET. RASSF1A furthermore represses miR-21 [100]. Interestingly overexpression of miR-21 which is also upregulated in PDAC, was strongly associated with both a high Ki67 proliferation index and metastasis to the liver [101], potentially giving the RAS pathway a role in higher grades of PanNET [54].

\section{MicroRNA}

Studies of microRNA expression have suggested that miR-193b is a differential marker for PanNET in tissue and serum compared to normal [102]. MiR-103 and miR-107 were also overexpressed and miR-155 was downregulated in PanNET [101].

\section{Changes in gene expression}

Analyses of gene-expression patterns in PanNETs have found that a number of genes are upregulated in PanNETs, including oncogenes (e.g. MLLT10/AF10), cell adhesion molecules (e.g. fibronectin) and growth factors (e.g. IGFBP3) compared to normal islets. Growth factor IGFBP3 was upregulated significantly more in metastases compared to primary PanNETs. In addition, downregulation of tumor suppressor genes (NME3), cell checkpoint proteins (p21/ Cip1), and transcription factor JunD that is inhibited by Menin, have been reported [103]. Comparison of gene expression between sporadic PanNETs and VHL associated 
PanNETs, found that VHL associated tumors follow a specific pathway with upregulation of genes related to hypoxia inducible factor proteins (HIF) and vascular endothelial growth factor (VEGF), both of which regulate angiogenesis [104].

Therapeutically, PanNETs relying on angiogenesis are theoretically targetable by blocking specific pathway components (e.g. VEGF inhibitors) [105-107]. Similarly, PanNETs relying on mTOR activation should be particularly susceptible to everolimus, a drug which has shown to significantly prolong survival [108].

\section{Solid-pseudopapillary neoplasms}

Solid-pseudopapillary neoplasms (SPN) are rare tumors accounting for 1-2 \% of all malignant neoplasms of the pancreas. These neoplasms mostly occur in female (90\%) patients at an average age of 29 years (SD: 14). SPNs have a low malignant potential. SPNs are usually limited to the pancreas, but $8 \%$ of patients present with distant metastasis. Disease free survival after curative resection is $95 \%$ [109].

\section{Gross and microscopic findings}

SPNs are essentially solid neoplasms that often undergo dramatic cystic degeneration creating a gross lesion with a mixture of solid, pseudopapillary and hemorrhagicnecrotic areas (Fig. 5a). Microscopically, these neoplasms are composed of poorly cohesive uniform cells clinging ineffectively to delicate capillaries surrounded by extensive degenerative changes. The cells have eosinophilic or clear vacuolated cytoplasm, and the nuclei are round to oval and can be often grooved or indented. Rarely the nuclei are bizarre appearing in areas with degeneration. Eosinophilic globules and foamy macrophages are typically present in these neoplasms (Fig. 5b). SPNs can be distinguished from other pancreatic tumors by the expression of CD10, paranuclear dot-like CD99 labeling and abnormal nuclear labeling for $\beta$-catenin (Fig. 5c) or lymphoid enhancer-binding factor 1 (LEF1) [110-114]. The microscopic differential diagnosis consists of neoplasms with a solid and cellular appearance like pancreatic neuroendocrine tumor, acinar cell carcinoma and pancreatoblastoma (Table 1).

\section{Genetic signatures: sporadic and familial SPN}

Activating mutations in CTNNB1 ( $\beta$-catenin) occur in virtually all SPNs, reflected by the nuclear accumulation of $\beta$-catenin seen in immunohistochemistry $[115,116]$. Recent whole exome sequencing of SPNs found on average of only three non-synonymous mutations per tumor, which is extremely low compared to all of the other pancreatic neoplasms. The CTNNB1 gene mutations all occur in the critical region between codons 32 and 37 preventing phosphorylation and subsequent degradation of the $\beta$-catenin protein.

Two SPNs have been reported in patients with Familial Adenomatous Polyposis (FAP), caused by germline APC mutations, confirming that an $A P C$ mutation is also capable of driving SPN development $[117,118]$. The female predominance of SPN is not understood, but it has been shown that estrogenic molecules can influence proliferation in vitro [119].

\section{Epigenetic alterations}

Undegraded $\beta$-catenin in SPNs forms a complex with LEF1, enters the nucleus and activates transcription of several oncogenes including cyclin-D1 that is overexpressed in $70-100 \%$ of SPNs $[115,116,120]$. Cyclin-D1 and its cyclin-dependent kinases phosphorylate the Retinoblastoma $(\mathrm{Rb})$ protein, which drives the cell in the S-phase of the cell cycle. P21 and P27, known to inhibit Rb phosphorylation, were shown to be upregulated in 86 and $100 \%$ of SPNs, respectively. Interestingly, hyperphosphorylated $\mathrm{Rb}$ was not detectable, which might explain the low growth-rate of SPN compared to other $\beta$-catenin mutated tumors [121].

\section{MicroRNA and changes in gene expression}

Few studies investigated gene expression and epigenetic alterations in SPN, and all are complicated by the fact that the normal cell that is the counterpart of the neoplastic cell in SPNs has not been identified. These studies are therefore, at best, comparing apples to oranges. One study investigated mRNA and miR expression in 14 SPNs and found 1686 genes to be differentially expressed compared to normal pancreatic parenchyma (which is composed mostly of acinar cells) [122]. These differentially expressed genes activated the Wnt pathway, Hedgehog $(\mathrm{HH})$ pathway, androgen-receptor (AR) pathway and epithelial mesenchymal transition. Moreover, 79 miRs were differentially expressed in these SPNs (49 miRs upregulated, 30 miRs downregulated). By predicting miR targets, 17 of the 30 downregulated miRs possibly upregulated mRNAs in the Wnt/HH/AR pathways [123]. A proteomic profile did not significantly confirm these pathways, but did find upregulation of several proteins involved in the Wnt pathway [122]. Another mRNA analysis in SPN found the NOTCH pathway to be activated in addition to the Wnt Pathway [124]. Large chromosomal rearrangements, aberrant methylation or other non-coding RNAs have not been investigated in SPN.

\section{Acinar cell carcinoma}

Acinar cell carcinoma (ACC) is a rare neoplasm accounting for $<1 \%$ of malignant pancreatic tumors. Median age of presentation is 56 years (SD: 15). Most cases occur in late adulthood, but $6 \%$ of cases occur between 8 and 15 years of age. There is no clear syndrome associated with ACC, 


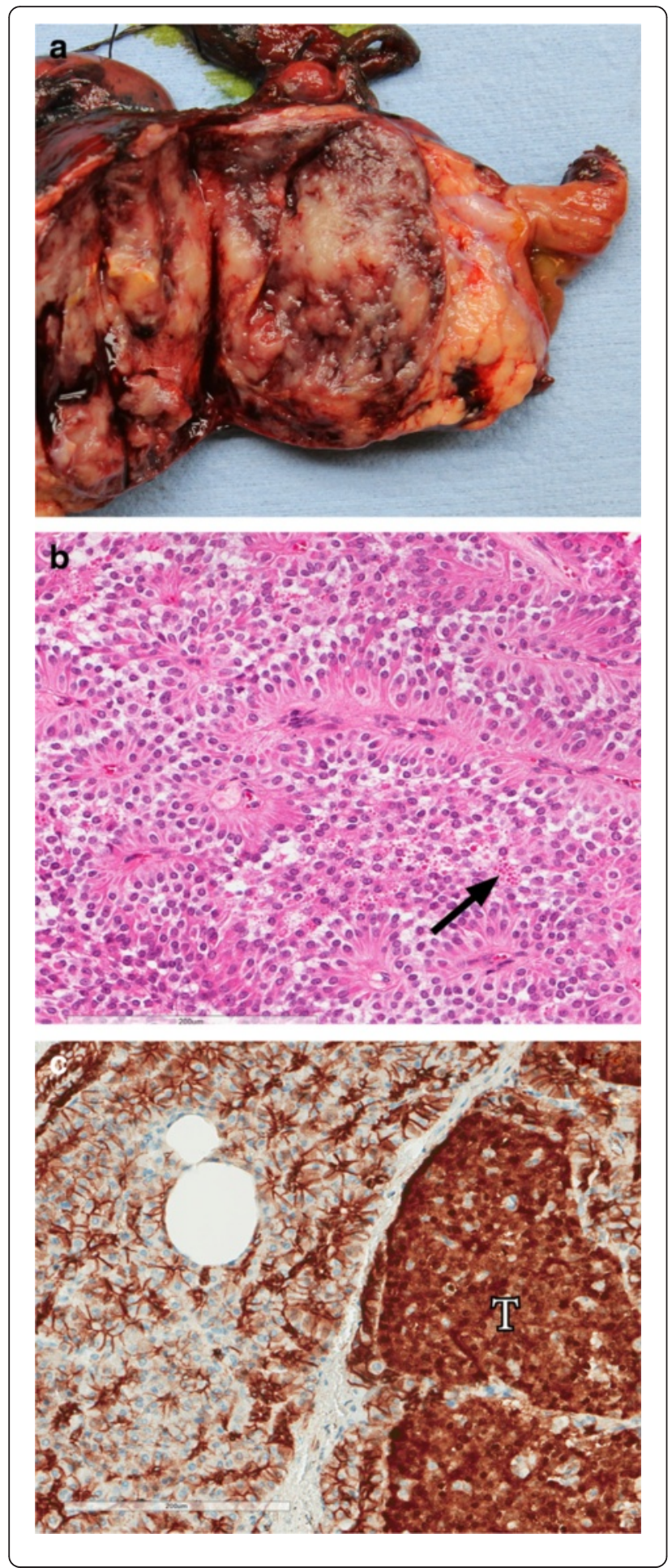

Fig. 5 a Macroscopic appearance of a solid-pseudopapillary neoplasm showing a well demarcated tumor with solid, pseudopapillary and hemorrhagic-necrotic pseudocystic structures. b Microscopically, SPN is characterized by solid areas with relatively uniform cells with eosinophilic or clear vacuolated cytoplasm admixed with delicate capillaries and areas with extensive degenerative changes. The cells are poorly cohesive causing the pseudopapillary appearance. Note the eosinophilic globules (arrow). c Nuclear $\beta$-catenin expression in SPN ( $T$ tumor) and normal membranous labelling in adjacent normal pancreatic parenchyma

but ACC has been reported in patients with Peutz-Jeghers syndrome, Lynch syndrome, Familial Adenomatous Polyposis, and in a patient with a germline BRCA1 mutation [125-128].

Although $60 \%$ of patients with ACC have distant metastasis at presentation (similar to PDAC), overall 5 -year survival is $45 \%$ [129]. Some ACCs release digestive enzymes and other products into the blood stream, including alpha-fetoprotein and lipase [130, 131]. About $15 \%$ of patients with ACC present with metastatic fat necrosis, peripheral eosinophilia and arthralgias caused by elevated serum lipase [132].

\section{Gross and microscopic findings}

Compared to PDAC, ACCs are relatively soft and wellcircumscribed tumors. Microscopically, ACCs are reminiscent of normal exocrine pancreatic cells with enlarged uniform nuclei with prominent nucleoli and finely granular eosinophilic cytoplasm. The cells can form small acinar units or sheets without a distinctive architecture (Fig. 6a and b) [5]. Acinar cell carcinomas express pancreatic exocrine enzymes such as trypsin, chymotrypsin and lipase that can be detectable by immunohistochemistry [132]. BCL10, normally expressed in normal acini, is also expressed in ACC and is helpful in the differential diagnosis between ACC and other pancreatic neoplasms such as PanNET and PDAC (Fig. $7 \mathrm{a}$ and b) [133, 134]. Also the monoclonal antibody 2P-1-2-1 can be used to show acinar differentiation [135]. The microscopic differential diagnosis consists of neoplasms with a solid and cellular appearance like pancreatic neuroendocrine tumor, solid pseudopapillary neoplasm, pancreatoblastoma (Table 1).

\section{Genetic signature: sporadic ACC}

Whole exome sequencing of ACCs revealed that these tumors, on average, harbor a large number of mutations (131 nonsynonymous somatic mutations per tumor in one study). Also, chromosomal instability is seen with a relative high fractional allelic loss compared to PDAC. Chromosome $11 \mathrm{p}$ is lost in $~ 50 \%$ of ACC, suggesting that a locus on 11p may play an important role in ACC development $[136,137]$. Many other gains and losses have been reported including loss of the TP53 locus on 17p (25\%), 


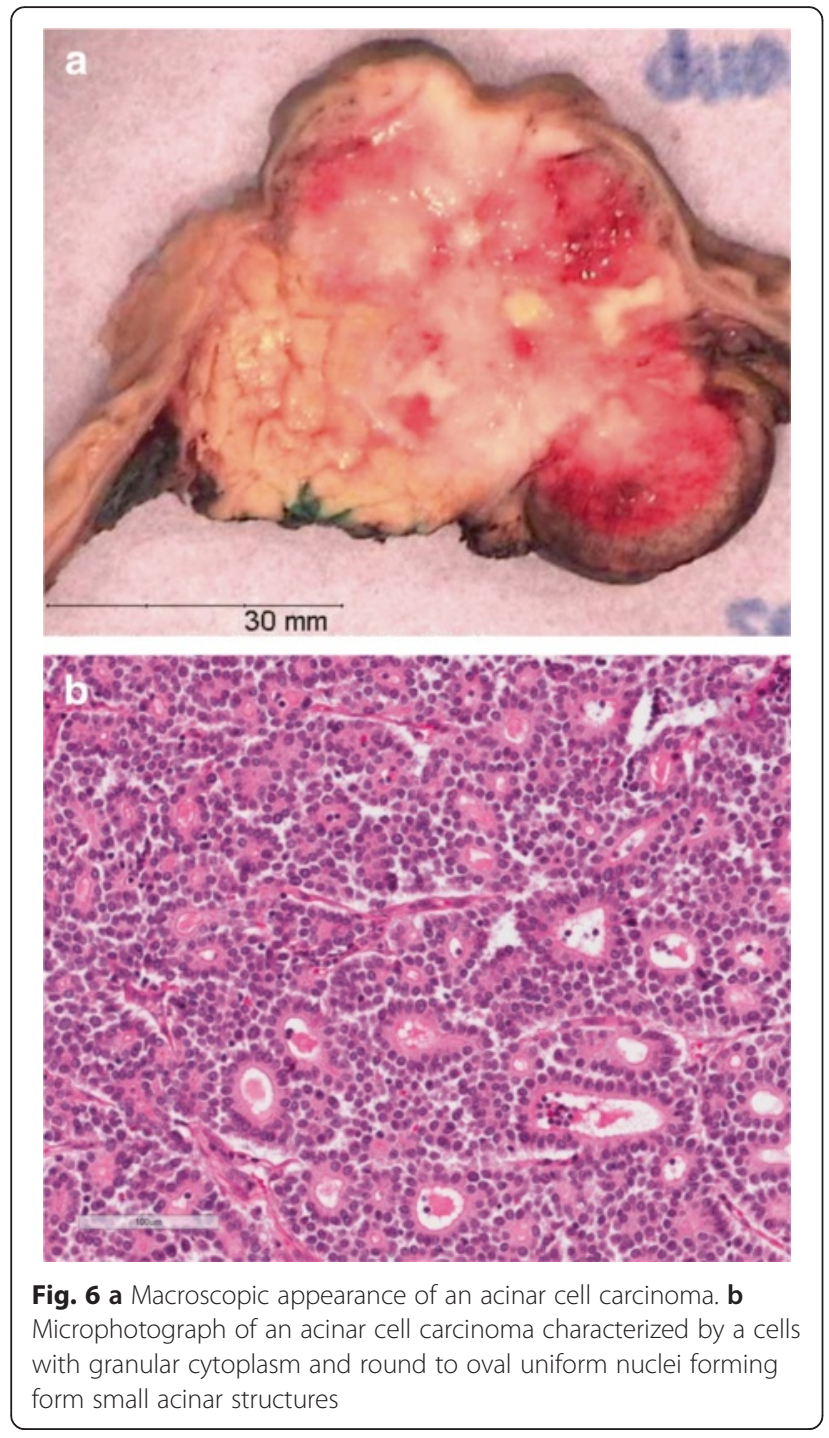

the $A P C$ locus on $5 \mathrm{q} 21$ (50\%), the SMAD4 locus on $18 \mathrm{q}$ $(60 \%)$ and gain of the CTNNB1 ( $\beta$-catenin) locus on $3 \mathrm{p}$ [137-140]. Whole exome sequencing data further revealed that no single gene was mutated in more than $30 \%$ of ACCs. The genes targeted include SMAD4 (25\%); JAK1 (20 \%); BRAF, RB1, TP53 (13\% each); APC, ARID1A, GNAS, MLL3, PTEN (9\% each) and ATM, BAP1, BRCA2 PALB2, MEN1, RNF43 (4\% each) [137]. Recently, a review combined all ACC sequencing studies and found similar results: SMAD4 mutations in $19 \%$ of ACC, CTNNB1/ $A P C$ in $15 \%, T P 53$ in $12 \%$, and BRAF in $6 \%$ [139].

Ten percent of ACCs appear to be microsatellite instable and may thus be sensitive to immunotherapy $[19,139]$. In addition, a number of other potentially actionable mutations, such as BRCA and JAK1 mutations, have been found in ACCs [137]. BRAF mutations are rarely seen in ACC; notably, comprehensive genomic profiling identified rearrangements in $23 \%$
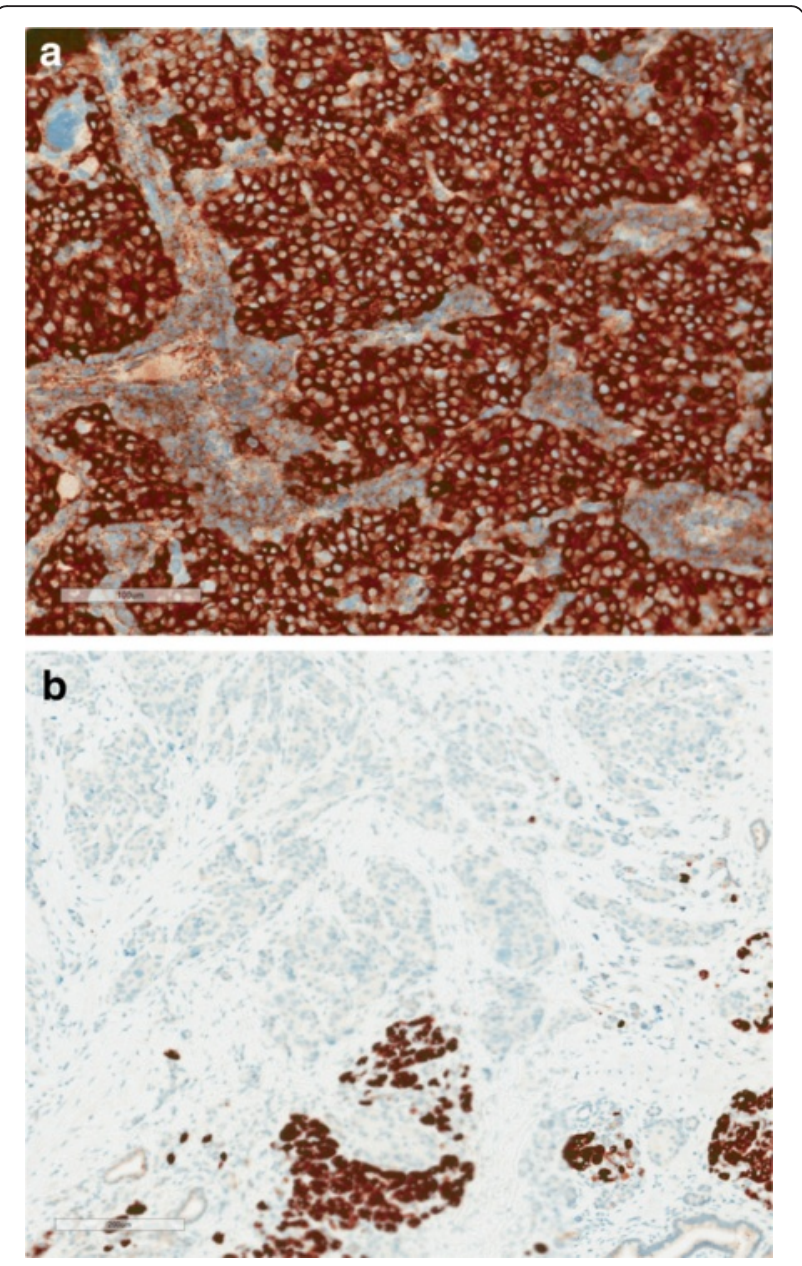

Fig. 7 a Positive BCL10 expression in an acinar cell carcinoma. b Negative BCL10 expression in a pancreatic neuroendocrine tumor

of ACC involving either BRAF or RAS. The most prevalent fusion SND1-BRAF activated the MAPK pathway and made the cells sensitive for MEK inhibitor trametinib, so this pathway might be useful as therapeutic target for a subgroup of patients with ACC [141].

\section{Epigenetic alterations and MicroRNA}

The importance of the $A P C / \beta$-catenin pathway for ACC becomes more evident when methylation is taken into account. RASSF1 and APC were reported to be methylated in 60 and $56 \%$ of ACCs, respectively [142]. A different study confirmed the high percentage of ACC with $A P C$ methylation, and also found significantly more MLH1 methylation in ACC compared to PDAC and PanNET [143].

MiR has only been studied in four ACCs in comparison to PanNETs. Surprisingly, $93 \%$ of differentially upregulated miRs and $70 \%$ of differentially downregulated miRs in 
ACC compared to normal pancreas were also up- or downregulated in PanNET. No specific miR was up- or downregulated in ACC versus PanNET. Overexpression of miR-17, miR-20, miR-21, miR-92-1, miR-103 and miR-107; and lack of expression of miR-155 was found in ACC [101].

\section{Pancreatoblastoma}

Pancreatoblastoma $(\mathrm{PB})$ is another rare tumor with acinar differentiation. PBs usually present in childhood at an average age of 5 years (SD: 2), but there is also a rare group that presents at adult age $[144,145]$. The overall 5 year survival is approximately $50 \%$. PB is associated with Beckwith-Wiedemann syndrome, an (epi)genetic overgrowth-cancer predisposition disorder characterized by exomphalos, macroglossia, and gigantism [146]. As in ACC, serum alpha-fetoprotein and lipase can be elevated in PB and pancreatic panniculitis has also been reported.

\section{Gross and microscopic findings}

Tumors are very similar to ACC in their acinar differentiation. The distinguishing element in $\mathrm{PB}$ from other tumors with acinar differentiation are characteristic squamoid nests, which can vary in size and appearance and can even show keratinization (Fig. 8). Neuroendocrine or ductal components may also be encountered, but acinar differentiation and squamoid nests are both required for the diagnosis. PB shares the same immunohistochemical markers for acinar differentiation with ACC, but can also stain positive for markers of ductal or neuroendocrine differentiation. SMAD4 expression is immunohistochemically lost in $20 \%$ [147], and abnormal nuclear expression of $\beta$-catenin can be seen, sometimes in the squamoid nests $[5,127]$. The microscopic differential diagnosis consists of neoplasms with a solid and cellular appearance like pancreatic neuroendocrine tumor, solid pseudopapillary neoplasm and acinar cell

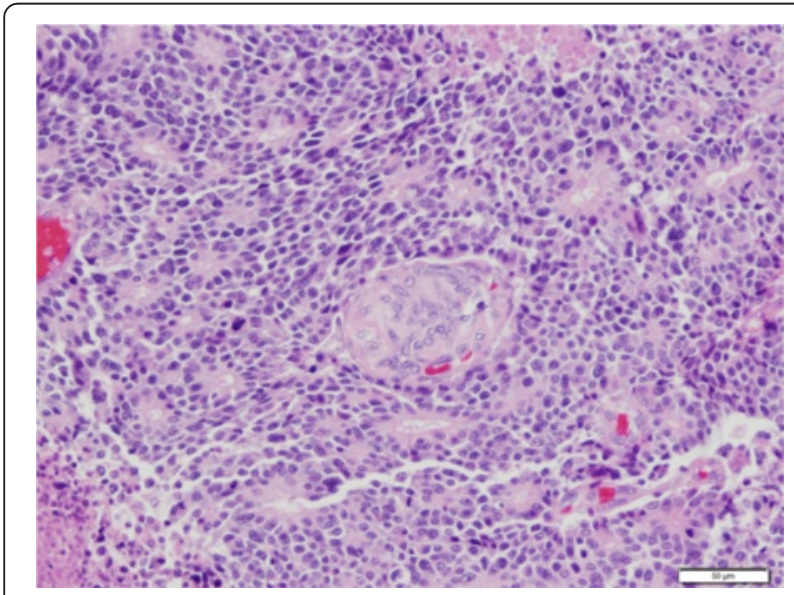

Fig. 8 Microphotograph of pancreatoblastoma showing characteristic squamoid nests carcinoma (Table 1). In children, other tumors like Wilms tumor and hepatoblastoma should be considered.

\section{Genetic signature and epigenetic alterations}

Patients with Beckwith-Wiedemann syndrome (germline loss of heterozygosity of chromosome 11p) have a significantly higher risk of pediatric tumors, amongst others pancreatoblastoma which has been reported in several BWS patients $[144,146]$. Interestingly loss of $11 p$ also occurs in more than $80 \%$ of sporadic PBs [147]. Likely, several genes on $11 \mathrm{p}$ that are expressed according to their parental origin (imprinting) play a role in $\mathrm{PB}$ tumorigenesis [148]. The $A P C / \beta$-catenin pathway also plays an important role with 40 to $60 \%$ of sporadic PBs having mutations in CTNN1B. In addition, a case with biallelic inactivation of $A P C$ in a FAP patient has been reported [115, 147]. Aberrant methylation of the promoter RASSF1A was seen in in 2 cases $[149,150]$. No further characterization in epigenetics has been done.

\section{Conclusions}

The underlying alterations of pancreatic cancer demonstrate that the traditional histopathologic classification of these neoplasms has a solid genetic basis. The genetic changes within each tumor type add to the pathologic classification with the identification of new prognostic markers and new therapeutic targets.

Even with all of the advances in our understanding of genetics of pancreatic neoplasms, the cornerstone to a correct diagnosis is still traditional gross and microscopic examination. Especially the importance of gross inspection is often less appreciated, and yet this can already give important clues to a correct diagnosis. For instance, some tumors are typically solid whereas others are typically cystic. Also, location of a tumor in the pancreas (head, body of tail) and whether a tumor is well circumscribed or ill-defined can point in a certain direction. Most diagnoses of pancreatic tumors can be made without help of additional genetic studies although sometimes proof of a specific genetic alteration in a tumor can further establish a presumed diagnosis. The best example clearly is the SPN, in which virtually all cases have the same underlying CTNNB1 mutation and immunohistochemistry for $\beta$-catenin is routinely used in the diagnostic workup. Also, loss of SMAD4 immunohistochemistry is frequently used in daily practice to suggest pancreatic origin of an adenocarcinoma in a distant site in a patient with a pancreatic mass.

Slowly we are heading towards an era where the combination of classical morphologic pathology and genetic characterization will be essential to establish a more accurate diagnosis. Furthermore, genetic profiling is becoming more and more important for treatment choices; for 
instance with the choice for a targeted therapy, such as mTOR inhibitors in pancreatic neuroendocrine tumors or PARP inhibitors in BRCA deficient tumors. In the near future, stromal activation, miRNA and methylation markers might influence our choices by better predicting tumor behavior and prognosis. Ideally, would use our knowledge of genetic and epigenetic alterations to screen the blood and pancreatic juices for genetic alteration that identify patients with a high-risk precursor lesion or an early form of cancer. Although our understanding of the genetics of pancreatic cancer has immensely increased in the last decade, many years of research are still needed to integrate all this knowledge and translate it into day-to-day practice.

\author{
Acknowledgements \\ Dutch Cancer Society (KWF). \\ Lisa Waller Hayes Foundation. \\ Nijbakker-Morra foundation. \\ Dutch Digestive Foundation (MLDS; CDG 14-02).
}

\section{Authors' contributions}

WMH drafted the manuscript, LAAB, RHH and GJAO helped to draft and revise the manuscript. All authors read and approved the final manuscript.

\section{Competing interests}

WMH, LAAB and GJAO have no competing interests to declare. $\mathrm{RHH}$ receives royalty payments from Myriad Genetics for the PALB2 invention, and RHH is on the Board of MiDiagnostics. Both relationships are overseen by the Johns Hopkins Office of Policy Coordination.

\section{Author details}

'Department of Pathology, University Medical Center Utrecht, Heidelberglaan 100, 3584 CX Utrecht, The Netherlands. 'Department of Pathology, The Sol Goldman Pancreatic Cancer Research Center, The Johns Hopkins University School of Medicine, Baltimore, MD, USA.

Received: 19 January 2016 Accepted: 28 May 2016

Published online: 07 June 2016

\section{References}

1. $Y u$ J, Blackford AL, Dal Molin M, Wolfgang CL, Goggins M. Time to progression of pancreatic ductal adenocarcinoma from low-to-high tumour stages. Gut. 2015;64:1783-9.

2. Siegel RL, Miller KD, Jemal A. Cancer statistics, 2015. CA Cancer J Clin. 2015;65:5-29.

3. Vincent A, Herman J, Schulick R, Hruban RH, Goggins M. Pancreatic cancer. Lancet. 2011:378:607-20.

4. Rahib L, Smith BD, Aizenberg R, Rosenzweig AB, Fleshman JM, Matrisian LM. Projecting cancer incidence and deaths to 2030: the unexpected burden of thyroid, liver, and pancreas cancers in the United States. Cancer Res. 2014;74:2913-21.

5. Bosman FT, Carneiro F, Hruban RH. WHO classification of tumours of the digestive system. World Health Organization; 2010. http://link.springer.com/ article/10.1007\%2Fs00534-006-1169-2.

6. Hruban $\mathrm{RH}$, Pitman MB, Klimstra DS. Tumors of the pancreas. American Registry of Pathology; 2007. http://link.springer.com/article/10. 1007\%2Fs00534-006-1169-2.

7. Terada T, Ohta T, Sasaki M, Nakanuma Y, Kim YS. Expression of MUC apomucins in normal pancreas and pancreatic tumours. J Pathol. 1996;180:160-5.

8. Nagata K, Horinouchi M, Saitou M, Higashi M, Nomoto M, Goto M, et al. Mucin expression profile in pancreatic cancer and the precursor lesions. J Hepatobiliary Pancreat Surg. 2007;14:243-54.

9. Takeda S, Nakao A, Ichihara T, Suzuki Y, Nonami T, Harada A, et al. Serum concentration and immunohistochemical localization of SPan-1 antigen in pancreatic cancer. A comparison with CA19-9 antigen.

Hepatogastroenterology. 1991;38:143-8.
10. Brosens LAA, Hackeng WM, Offerhaus GJ, Hruban RH, Wood LD. Pancreatic adenocarcinoma pathology: changing "landscape". J Gastrointest Oncol. 2015;6:358-74.

11. Basturk O, Hong S-M, Wood LD, Adsay NV, Albores-Saavedra J, Biankin AV et al. A revised classification system and recommendations from the Baltimore Consensus Meeting for neoplastic precursor lesions in the pancreas. Am J Surg Pathol. 2015;39:1730-41.

12. Roberts NJ, Norris AL, Petersen GM, Bondy ML, Brand R, Gallinger S, et al. Whole genome sequencing defines the genetic heterogeneity of familial pancreatic cancer. Cancer Discov 2015:CD-15-0402.

13. Jones S, Hruban RH, Kamiyama M, Borges M, Zhang X, Parsons DW, et al. Exomic sequencing identifies PALB2 as a pancreatic cancer susceptibility gene. Science. 2009;324:217.

14. Zhen DB, Rabe KG, Gallinger S, Syngal S, Schwartz AG, Goggins MG, et al. BRCA1, BRCA2, PALB2, and CDKN2A mutations in familial pancreatic cancer: a PACGENE study. Genet Med. 2015;17:569-77.

15. Roberts NJ, Jiao Y, Yu J, Kopelovich L, Petersen GM, Bondy ML, et al. ATM mutations in patients with hereditary pancreatic cancer. Cancer Discov. 2012;2:41-6.

16. Hearle N, Schumacher V, Menko FH, Olschwang S, Boardman LA, Gille JJP, et al. Frequency and spectrum of cancers in the Peutz-Jeghers syndrome. Clin Cancer Res. 2006;12:3209-15.

17. Kastrinos F, Mukherjee B, Tayob N, Wang F, Sparr J, Raymond VM, et al. Risk of pancreatic cancer in families with Lynch syndrome. JAMA. 2009:302:1790-5

18. Canto MI, Harinck F, Hruban RH, Offerhaus GJ, Poley J-W, Kamel I, et al. International Cancer of the Pancreas Screening (CAPS) Consortium summit on the management of patients with increased risk for familial pancreatic cancer. 2013. p. 339-47.

19. Le DT, Uram JN, Wang H, Bartlett BR, Kemberling H, Eyring AD, et al. PD-1 blockade in tumors with mismatch-repair deficiency. N Engl J Med. 2015:372:2509-20

20. Bhalla A, Saif MW. PARP-inhibitors in BRCA-associated pancreatic cancer JOP. 2014;15:340-3.

21. Waddell N, Pajic M, Patch A-M, Chang DK, Kassahn KS, Bailey P, et al. Whole genomes redefine the mutational landscape of pancreatic cancer. Nature. 2015;518:495-501.

22. Childs EJ, Mocci E, Campa D, Bracci PM, Gallinger S, Goggins M, et al. Common variation at 2p13.3, 3q29, 7p13 and 17q25.1 associated with susceptibility to pancreatic cancer. Nat Genet. 2015;47:911-6.

23. Wolpin BM, Rizzato C, Kraft P, Kooperberg C, Petersen GM, Wang Z, et al. Genome-wide association study identifies multiple susceptibility loci for pancreatic cancer. Nat Genet. 2014;46:994-1000.

24. Wolpin BM, Kraft P, Xu M, Steplowski E, Olsson ML, Arslan AA, et al. Variant $\mathrm{ABO}$ blood group alleles, secretor status, and risk of pancreatic cancer: results from the pancreatic cancer cohort consortium. Cancer Epidemiol Biomarkers Prev. 2010;19:3140-9.

25. Biankin AV, Waddell N, Kassahn KS, Gingras M-C, Muthuswamy LB, Johns AL, et al. Pancreatic cancer genomes reveal aberrations in axon guidance pathway genes. Nature. 2012;491:399-405.

26. Jones S, Zhang X, Parsons DW, Lin JC-H, Leary RJ, Angenendt P, et al. Core signaling pathways in human pancreatic cancers revealed by global genomic analyses. Science. 2008;321:1801-6.

27. Witkiewicz AK, McMillan EA, Balaji U, Baek G, Lin W-C, Mansour J, et al. Whole-exome sequencing of pancreatic cancer defines genetic diversity and therapeutic targets. Nat Commun. 2015;6:6744.

28. Griffin CA, Hruban RH, Morsberger LA, Ellingham T, Long PP, Jaffee EM, et al. Consistent chromosome abnormalities in adenocarcinoma of the pancreas. Cancer Res. 1995:55:2394-9.

29. Sausen M, Phallen J, Adleff V, Jones S, Leary RJ, Barrett MT, et al. Clinical implications of genomic alterations in the tumour and circulation of pancreatic cancer patients. Nat Commun. 2015;6:7686.

30. Blackford A, Serrano OK, Wolfgang CL, Parmigiani G, Jones S, Zhang X, et al. SMAD4 gene mutations are associated with poor prognosis in pancreatic cancer. Clin Cancer Res. 2009:15:4674-9.

31. Castro-Giner F, Ratcliffe P, Tomlinson I. The mini-driver model of polygenic cancer evolution. Nat Rev Cancer. 2015;15:680-5.

32. Yachida S, Jones S, Bozic I, Antal T, Leary R, Fu B, et al. Distant metastasis occurs late during the genetic evolution of pancreatic cancer. Nature. 2010;467:1114-7. 
33. Bettegowda C, Sausen M, Leary RJ, Kinde I, Wang Y, Agrawal N, et al. Detection of circulating tumor DNA in early- and late-stage human malignancies. Sci Transl Med. 2014;6:224ra24-4.

34. Springer S, Wang Y, Dal Molin M, Masica DL, Jiao Y, Kinde I, et al. A combination of molecular markers and clinical features improve the classification of pancreatic cysts. Gastroenterology. 2015;149:1501-10.

35. Shimizu H, Horii A, Sunamura M, Motoi F, Egawa S, Unno M, et al. Identification of epigenetically silenced genes in human pancreatic cancer by a novel method "microarray coupled with methyl-CpG targeted transcriptional activation" (MeTA-array). Biochem Biophys Res Commun, 2011:411:162-7.

36. Tan AC, Jimeno A, Lin SH, Wheelhouse J, Chan F, Solomon A, et al. Characterizing DNA methylation patterns in pancreatic cancer genome. $\mathrm{Mol}$ Oncol. 2009;3:425-38.

37. Vincent A, Omura N, Hong S-M, Jaffe A, Eshleman J, Goggins M. Genomewide analysis of promoter methylation associated with gene expression profile in pancreatic adenocarcinoma. Clin Cancer Res. 2011;17:4341-54

38. Nones K, Waddell N, Song S, Patch A-M, Miller D, Johns A, et al. Genomewide DNA methylation patterns in pancreatic ductal adenocarcinoma reveal epigenetic deregulation of SLIT-ROBO, ITGA2 and MET signaling. Int J Cancer. 2014;135:1110-8.

39. Omura N, Li C-P, Li A, Hong S-M, Walter K, Jimeno A, et al. Genome-wide profiling of methylated promoters in pancreatic adenocarcinoma. Cancer Biol Ther. 2008;7:1146-56.

40. Zhao Y, Sun J, Zhang H, Guo S, Gu J, Wang W, et al. High-frequency aberrantly methylated targets in pancreatic adenocarcinoma identified via global DNA methylation analysis using methylCap-seq. Clin Epigenetics. 2014;6:18.

41. Sato N, Fukushima N, Maitra A, Matsubayashi H, Yeo CJ, Cameron JL, et al. Discovery of novel targets for aberrant methylation in pancreatic carcinoma using high-throughput microarrays. Cancer Res. 2003;63:3735-42.

42. Goonesekere NCW, Wang X, Ludwig L, Guda C. A meta analysis of pancreatic microarray datasets yields new targets as cancer genes and biomarkers. PLoS One. 2014;9, e93046.

43. Hong S-M, Park JY, Hruban RH, Goggins M. Molecular signatures of pancreatic cancer. Arch Pathol Lab Med. 2011;135:716-27.

44. Fukushima N, Sato N, Ueki T, Rosty C, Walter KM, Wilentz RE, et al. Aberrant methylation of preproenkephalin and p16 genes in pancreatic intraepithelial neoplasia and pancreatic ductal adenocarcinoma. Am J Pathol. 2002;160:1573-81.

45. Moore PS, Sipos B, Orlandini S, Sorio C, Real FX, Lemoine NR, et al. Genetic profile of 22 pancreatic carcinoma cell lines. Analysis of K-ras, p53, p16 and DPC4/Smad4. Virchows Arch. 2001;439:798-802.

46. Ueki T, Toyota M, Sohn T, Yeo CJ, Issa JP, Hruban RH, et al. Hypermethylation of multiple genes in pancreatic adenocarcinoma. Cancer Res. 2000;60:1835-9.

47. Matsubayashi H, Canto M, Sato N, Klein A, Abe T, Yamashita K, et al. DNA methylation alterations in the pancreatic juice of patients with suspected pancreatic disease. Cancer Res. 2006;66:1208-17.

48. Habbe N, Koorstra J-BM, Mendell JT, Offerhaus GJ, Ryu JK, Feldmann G, et al. MicroRNA miR-155 is a biomarker of early pancreatic neoplasia. Cancer Biol Ther. 2009:8:340-6.

49. Frampton AE, Krell J, Jamieson NB, Gall TMH, Giovannetti E, Funel N, et al. microRNAs with prognostic significance in pancreatic ductal adenocarcinoma: a meta-analysis. Eur J Cancer. 2015;51:1389-404.

50. Ma M-Z, Kong X, Weng M-Z, Cheng K, Gong W, Quan Z-W, et al. Candidate microRNA biomarkers of pancreatic ductal adenocarcinoma: meta-analysis, experimental validation and clinical significance. J Exp Clin Cancer Res. 2013;32:71.

51. Yang J-Y, Sun Y-W, Liu D-J, Zhang J-F, Li J, Hua R. MicroRNAs in stool samples as potential screening biomarkers for pancreatic ductal adenocarcinoma cancer. Am J Cancer Res. 2014:4:663-73.

52. Abue M, Yokoyama M, Shibuya R, Tamai K, Yamaguchi K, Sato I, et al. Circulating miR-483-3p and miR-21 is highly expressed in plasma of pancreatic cancer. Int J Oncol. 2015;46(2):539-47.

53. Volinia S, Calin GA, Liu C-G, Ambs S, Cimmino A, Petrocca F, et al. A microRNA expression signature of human solid tumors defines cancer gene targets. Proc Natl Acad Sci U S A. 2006;103:2257-61.

54. Hatley ME, Patrick DM, Garcia MR, Richardson JA, Bassel-Duby R, van Rooij E, et al. Modulation of K-Ras-dependent lung tumorigenesis by MicroRNA-21. Cancer Cell. 2010;18:282-93.

55. Selcuklu SD, Donoghue MTA, Spillane C. miR-21 as a key regulator of oncogenic processes. Biochem Soc Trans. 2009;37:918-25.
56. Toste PA, Li L, Kadera BE, Nguyen AH, Tran LM, Wu N, et al. p85a is a microRNA target and affects chemosensitivity in pancreatic cancer. J Surg Res. 2015;196:285-93.

57. Wang C, Sun Y, Wu H, Yu S, Zhang L, Meng Y, et al. Elevated miR-483-3p expression is an early event and indicates poor prognosis in pancreatic ductal adenocarcinoma. Tumour Biol. 2015;36(12):9447-56.

58. Bai Z, Sun J, Wang X, Wang H, Pei H, Zhang Z. MicroRNA-153 is a prognostic marker and inhibits cell migration and invasion by targeting SNAl1 in human pancreatic ductal adenocarcinoma. Oncol Rep. 2015;34:595-602.

59. Xia X, Zhang K, Cen G, Jiang T, Cao J, Huang K, et al. MicroRNA-301a-3p promotes pancreatic cancer progression via negative regulation of SMAD4. Oncotarget. 2015;6:21046-63.

60. Zhu Z, Xu Y, Zhao J, Liu Q, Feng W, Fan J, et al. miR-367 promotes epithelial-to-mesenchymal transition and invasion of pancreatic ductal adenocarcinoma cells by targeting the Smad7-TGF- $\beta$ signalling pathway. Br J Cancer. 2015;112:1367-75.

61. Müller S, Raulefs S, Bruns P, Afonso-Grunz F, Plötner A, Thermann R, et al. Next-generation sequencing reveals novel differentially regulated mRNAs, IncRNAs, miRNAs, sdRNAs and a piRNA in pancreatic cancer. Mol Cancer. 2015;14:94.

62. Collisson EA, Sadanandam A, Olson P, Gibb WJ, Truitt M, Gu S, et al: Subtypes of pancreatic ductal adenocarcinoma and their differing responses to therapy. Nat Med. 2011;17:500-3.

63. Moffitt RA, Marayati R, Flate EL, Volmar KE, Loeza SGH, Hoadley KA, et al. Virtual microdissection identifies distinct tumor- and stroma-specific subtypes of pancreatic ductal adenocarcinoma. Nat Genet. 2015:47:1168-78.

64. Harsha HC, Kandasamy K, Ranganathan P, Rani S, Ramabadran S, Gollapudi $S$, et al. A compendium of potential biomarkers of pancreatic cancer. PLoS Med. 2009:6, e1000046.

65. Wang Q, Chaerkady R, Wu J, Hwang HJ, Papadopoulos N, Kopelovich L, et al. Mutant proteins as cancer-specific biomarkers. Proc Natl Acad Sci U S A. 2011;108:2444-9.

66. Zhang $Y$, Choi M. Immune therapy in pancreatic cancer: now and the future? Rev Recent Clin Trials. 2015;10:317-25.

67. Rosenberg SA, Restifo NP. Adoptive cell transfer as personalized immunotherapy for human cancer. Science. 2015;348:62-8.

68. Xu Z, Pothula SP, Wilson JS, Apte MV. Pancreatic cancer and its stroma: a conspiracy theory. World J Gastroenterol. 2014;20:11216-29.

69. Rhim AD, Oberstein PE, Thomas DH, Mirek ET, Palermo CF, Sastra SA, et al. Stromal elements act to restrain, rather than support, pancreatic ductal adenocarcinoma. Cancer Cell. 2014;25:735-47.

70. Stromnes IM, DelGiorno KE, Greenberg PD, Hingorani SR. Stromal reengineering to treat pancreas cancer. Carcinogenesis. 2014;35:1451-60.

71. Halfdanarson TR, Rabe KG, Rubin J, Petersen GM. Pancreatic neuroendocrine tumors (PNETs): incidence, prognosis and recent trend toward improved survival. Ann Oncol. 2008:19:1727-33.

72. Ries LAG, Young Jr JL, Keel GE, Eisner MP, Lin YD, Horner MJD. Cancer survival among adults. Bethesda, MD: US Department of Health and Human Services, National Institutes of Health, National Cancer Institute; 2007.

73. Falconi M, Eriksson B, Kaltsas G, Bartsch DK, Capdevila J, Caplin M, et al. Consensus guidelines update for the management of Functional p-NETs (F-p-NETs) and Non-Functional p-NETs (NF-p-NETs). Int J Oncol. 2015;46(2):539-47.

74. Rindi G, Falconi M, Klersy C, Albarello L, Boninsegna L, Buchler MW, et al. TNM staging of neoplasms of the endocrine pancreas: results from a large international cohort study. J Natl Cancer Inst. 2012;104:764-77.

75. Basturk O, Yang Z, Tang LH, Hruban RH, Adsay V, McCall CM, et al. The highgrade (WHO G3) pancreatic neuroendocrine tumor category is morphologically and biologically heterogenous and includes both well differentiated and poorly differentiated neoplasms. Am J Surg Pathol. 2015;39:683-90.

76. Solcia E, Klöppel G, Sobin LH. Histological typing of endocrine tumours. Berlin, Heidelberg: Springer Science \& Business Media; 2000.

77. Hammond EH, Yowell RL, Flinner RL. Neuroendocrine carcinomas: role of immunocytochemistry and electron microscopy. Hum Pathol. 1998:29:1367-71.

78. Yachida S, Vakiani E, White CM, Zhong Y, Saunders T, Morgan R, et al. Small cell and large cell neuroendocrine carcinomas of the pancreas are genetically similar and distinct from well-differentiated pancreatic neuroendocrine tumors. Am J Surg Pathol. 2012:36:173-84.

79. Sipos B, Sperveslage J, Anlauf M, Hoffmeister M, Henopp T, Buch S, et al. Glucagon cell hyperplasia and neoplasia with and without glucagon receptor mutations. J Clin Endocrinol Metab. 2015;100:E783-8. 
80. Klöppel G, Anlauf M, Perren A, Sipos B. Hyperplasia to neoplasia sequence of duodenal and pancreatic neuroendocrine diseases and pseudohyperplasia of the PP-cells in the pancreas. Endocr Pathol. 2014;25:181-5.

81. Esposito I, Segler A, Steiger K, Klöppel G. Pathology, genetics and precursors of human and experimental pancreatic neoplasms: an update. Int J Oncol. 2015:46(2):539-47.

82. Jiao Y, Shi C, Edil BH, de Wilde RF, Klimstra DS, Maitra A, et al. DAXX/ATRX, MEN1, and mTOR pathway genes are frequently altered in pancreatic neuroendocrine tumors. Science. 2011;331:1199-203.

83. Lubensky IA, Debelenko LV, Zhuang Z, Emmert-Buck MR, Dong Q, Chandrasekharappa S, et al. Allelic deletions on chromosome 11q13 in multiple tumors from individual MEN1 patients. Cancer Res. 1996;56:5272-8.

84. Görtz B, Roth J, Krähenmann A, de Krijger RR, Muletta-Feurer S, Rütimann K, et al. Mutations and allelic deletions of the MEN1 gene are associated with a subset of sporadic endocrine pancreatic and neuroendocrine tumors and not restricted to foregut neoplasms. Am J Pathol. 1999;154:429-36.

85. Heaphy CM, de Wilde RF, Jiao Y, Klein AP, Edil BH, Shi C, et al. Altered telomeres in tumors with ATRX and DAXX mutations. Science. 2011;333:425.

86. Yuan F, Shi M, Ji J, Shi H, Zhou C, Yu Y, et al. KRAS and DAXX/ATRX gene mutations are correlated with the clinicopathological features, advanced diseases, and poor prognosis in Chinese patients with pancreatic neuroendocrine tumors. Int J Biol Sci. 2014;10:957-65.

87. Marinoni I, Kurrer AS, Vassella E, Dettmer M, Rudolph T, Banz V, et al. Loss of DAXX and ATRX are associated with chromosome instability and reduced survival of patients with pancreatic neuroendocrine tumors. Gastroenterology. 2014;146:453-5

88. Schmitt AM, Schmid S, Rudolph T, Anlauf M, Prinz C, Klöppel G, et al. $\mathrm{VHL}$ inactivation is an important pathway for the development of malignant sporadic pancreatic endocrine tumors. Endocr Relat Cancer. 2009;16:1219-27.

89. Nikiforova MN, Nikiforov YE, Biddinger P, Gnepp DR, Grosembacher LA, Wajchenberg $B L$, et al. Frequent loss of heterozygosity at chromosome $3 p 14.2-3 p 21$ in human pancreatic islet cell tumours. Clin Endocrinol (Oxf). 1999:51:27-33

90. Ohki R, Saito K, Chen Y, Kawase T, Hiraoka N, Saigawa R, et al. PHLDA3 is a novel tumor suppressor of pancreatic neuroendocrine tumors. Proc Natl Acad Sci U S A. 2014;111:E2404-13.

91. Floridia G, Grilli G, Salvatore M, Pescucci C, Moore PS, Scarpa A, et al. Chromosomal alterations detected by comparative genomic hybridization in nonfunctioning endocrine pancreatic tumors. Cancer Genet Cytogenet. 2005;156:23-30

92. Hessman O, Skogseid B, Westin G, Akerström G. Multiple allelic deletions and intratumoral genetic heterogeneity in men 1 pancreatic tumors. J Clin Endocrinol Metab. 2001;86:1355-61

93. Hessman O, Lindberg D, Einarsson A, Lillhager P, Carling T, Grimelius L, et al. Genetic alterations on 3p, 11q13, and 18q in nonfamilial and MEN 1-associated pancreatic endocrine tumors. Genes Chromosomes Cancer. 1999;26:258-64.

94. Perren A, Anlauf M, Henopp T, Rudolph T, Schmitt A, Raffel A, et al. Multiple endocrine neoplasia type 1 (MEN1): loss of one MEN1 allele in tumors and monohormonal endocrine cell clusters but not in islet hyperplasia of the pancreas. J Clin Endocrinol Metab. 2007;92:1118-28.

95. de Wilde RF, Heaphy CM, Maitra A, Meeker AK, Edil BH, Wolfgang CL, et al. Loss of ATRX or DAXX expression and concomitant acquisition of the alternative lengthening of telomeres phenotype are late events in a small subset of MEN-1 syndrome pancreatic neuroendocrine tumors. Mod Pathol. 2012;25:1033-9.

96. Stefanoli M, La Rosa S, Sahnane N, Romualdi C, Pastorino R, Marando A, et al. Prognostic relevance of aberrant DNA methylation in $\mathrm{g} 1$ and g2 pancreatic neuroendocrine tumors. Neuroendocrinology. 2014;100:26-34.

97. House MG, Herman JG, Guo MZ, Hooker CM, Schulick RD, Lillemoe KD, et al. Aberrant hypermethylation of tumor suppressor genes in pancreatic endocrine neoplasms. Ann Surg. 2003;238:423-31. discussion 431-2.

98. Malpeli G, Amato E, Dandrea M, Fumagalli C, Debattisti V, Boninsegna L, et al. Methylation-associated down-regulation of RASSF1A and up-regulation of RASSF1C in pancreatic endocrine tumors. BMC Cancer. 2011;11:351.

99. Estrabaud E, Lassot I, Blot G, Le Rouzic E, Tanchou V, Quemeneur E, et al. RASSF1C, an isoform of the tumor suppressor RASSF1A, promotes the accumulation of beta-catenin by interacting with betaTrCP. Cancer Res. 2007;67:1054-61.

100. Ram RR, Mendiratta S, Bodemann BO, Torres MJ, Eskiocak U, White MA. RASSF1A inactivation unleashes a tumor suppressor/oncogene cascade with context-dependent consequences on cell cycle progression. Mol Cell Biol. 2014;34:2350-8.

101. Roldo C, Missiaglia E, Hagan JP, Falconi M, Capelli P, Bersani S, et al. MicroRNA expression abnormalities in pancreatic endocrine and acinar tumors are associated with distinctive pathologic features and clinical behavior. J Clin Oncol. 2006;24:4677-84.

102. Thorns C, Schurmann C, Gebauer N, Wallaschofski H, Kümpers C, Bernard V, et al. Global microRNA profiling of pancreatic neuroendocrine neoplasias. Anticancer Res. 2014;34:2249-54.

103. Maitra A, Hansel DE, Argani P, Ashfaq R, Rahman A, Naji A, et al. Global expression analysis of well-differentiated pancreatic endocrine neoplasms using oligonucleotide microarrays. Clin Cancer Res. 2003;9:5988-95.

104. Speisky D, Duces A, Bièche I, Rebours V, Hammel P, Sauvanet A, et al. Molecular profiling of pancreatic neuroendocrine tumors in sporadic and Von Hippel-Lindau patients. Clin Cancer Res. 2012;18:2838-49.

105. Raymond E, Dahan L, Raoul J-L, Bang Y-J, Borbath I, Lombard-Bohas C, et al. Sunitinib malate for the treatment of pancreatic neuroendocrine tumors. N Engl J Med. 2011;364:501-13.

106. Vinik Al, Raymond E. Pancreatic neuroendocrine tumors: approach to treatment with focus on sunitinib. Therap Adv Gastroenterol. 2013;6:396-411.

107. Pea A, Hruban RH, Wood LD. Genetics of pancreatic neuroendocrine tumors: implications for the clinic. Expert Rev Gastroenterol Hepatol. 2015;9:1407-19.

108. Yao JC, Shah MH, Ito T, Bohas CL, Wolin EM, Van Cutsem E, et al. Everolimus for advanced pancreatic neuroendocrine tumors. N Engl J Med. 2011;364:514-23.

109. Law JK, Ahmed A, Singh VK, Akshintala VS, Olson MT, Raman SP, et al. A systematic review of solid-pseudopapillary neoplasms: are these rare lesions? Pancreas. 2014;43:331-7.

110. Notohara K, Hamazaki S, Tsukayama C, Nakamoto S, Kawabata K, Mizobuchi K, et al. Solid-pseudopapillary tumor of the pancreas: immunohistochemical localization of neuroendocrine markers and CD10. Am J Surg Pathol. 2000;24:1361-71.

111. Miettinen $M$, Partanen S, Fräki O, Kivilaakso E. Papillary cystic tumor of the pancreas. An analysis of cellular differentiation by electron microscopy and immunohistochemistry. Am J Surg Pathol. 1987;11:855-65.

112. El-Bahrawy MA, Rowan A, Horncastle D, Tomlinson I, Theis BA, Russell RCG, et al. E-cadherin/catenin complex status in solid pseudopapillary tumor of the pancreas. Am J Surg Pathol. 2008;32:1-7.

113. Guo Y, Yuan F, Deng H, Wang H-F, Jin X-L, Xiao J-C. Paranuclear dot-like immunostaining for CD99: a unique staining pattern for diagnosing solidpseudopapillary neoplasm of the pancreas. Am J Surg Pathol. 2011;35:799-806.

114. Singhi AD, Lilo M, Hruban RH, Cressman KL, Fuhrer $K$, Seethala RR Overexpression of lymphoid enhancer-binding factor 1 (LEF1) in solidpseudopapillary neoplasms of the pancreas. Mod Pathol. 2014;27:1355-63.

115. Tanaka Y, Kato K, Notohara K, Hojo H, ljiri R, Miyake T, et al. Frequent betacatenin mutation and cytoplasmic/nuclear accumulation in pancreatic solidpseudopapillary neoplasm. Cancer Res. 2001;61:8401-4.

116. Abraham SC, Klimstra DS, Wilentz RE, Yeo CJ, Conlon K, Brennan M, et al. Solid-pseudopapillary tumors of the pancreas are genetically distinct from pancreatic ductal adenocarcinomas and almost always harbor beta-catenin mutations. Am J Pathol. 2002;160:1361-9.

117. Ruo L, Coit DG, Brennan MF, Guillem JG. Long-term follow-up of patients with familial adenomatous polyposis undergoing pancreaticoduodenal surgery. J Gastrointest Surg. 2002:6:671-5.

118. Inoue T, Nishi Y, Okumura F, Mizushima T, Nishie H, Iwasaki H, et al. Solid pseudopapillary neoplasm of the pancreas associated with familial adenomatous polyposis. Intern Med. 2015;54:1349-55.

119. Tognarini I, Tonelli F, Nesi G, Martineti V, Galli G, Gozzini A, et al. In vitro effects of oestrogens, antioestrogens and SERMs on pancreatic solid pseudopapillary neoplasm-derived primary cell culture. Cell Oncol. 2010;32:331-43.

120. Müller-Höcker J, Zietz CH, Sendelhofert A. Deregulated expression of cell cycle-associated proteins in solid pseudopapillary tumor of the pancreas. Mod Pathol. 2001:14:47-53.

121. Tiemann K, Heitling U, Kosmahl M, Klöppel G. Solid pseudopapillary neoplasms of the pancreas show an interruption of the Wnt-signaling pathway and express gene products of 11q. Mod Pathol. 2007;20:955-60.

122. Park M, Lim J-S, Lee H-J, Na K, Lee MJ, Kang CM, et al. Distinct protein expression profiles of solid-pseudopapillary neoplasms of the pancreas. J Proteome Res. 2015;14:3007-14. 
123. Park M, Kim M, Hwang D, Park M, Kim WK, Kim SK, et al. Characterization of gene expression and activated signaling pathways in solid-pseudopapillary neoplasm of pancreas. Mod Pathol. 2014;27:580-93.

124. Cavard C, Audebourg A, Letourneur F, Audard V, Beuvon F, Cagnard N, et al. Gene expression profiling provides insights into the pathways involved in solid pseudopapillary neoplasm of the pancreas. J Pathol. 2009;218:201-9.

125. Seket B, Saurin J-C, Scoazec J-Y, Partensky C. [Pancreatic acinar cell carcinoma in a patient with familial adenomatous polyposis]. Gastroenterol Clin Biol. 2003;27:818-20.

126. Lowery MA, Klimstra DS, Shia J, Yu KH, Allen PJ, Brennan MF, et al. Acinar cell carcinoma of the pancreas: new genetic and treatment insights into a rare malignancy. Oncologist. 2011;16:1714-20.

127. de Wilde RF, Ottenhof NA, Jansen M, Morsink FHM, de Leng WWJ, Offerhaus GJA, et al. Analysis of LKB1 mutations and other molecular alterations in pancreatic acinar cell carcinoma. Mod Pathol. 2011;24:1229-36.

128. Liu W, Shia J, Gönen M, Lowery MA, O'Reilly EM, Klimstra DS. DNA mismatch repair abnormalities in acinar cell carcinoma of the pancreas: frequency and clinical significance. Pancreas. 2014;43:1264-70.

129. Wisnoski NC, Townsend CM, Nealon WH, Freeman JL, Riall TS. 672 patients with acinar cell carcinoma of the pancreas: a population-based comparison to pancreatic adenocarcinoma. Surgery. 2008;144:141-8.

130. Cingolani N, Shaco-Levy R, Farruggio A, Klimstra DS, Rosai J. Alphafetoprotein production by pancreatic tumors exhibiting acinar cell differentiation: study of five cases, one arising in a mediastinal teratoma. Hum Pathol. 2000;31:938-44

131. Ono J, Sakamoto H, Sakoda K, Yagi Y, Hagio S, Sato E, et al. Acinar cell carcinoma of the pancreas with elevated serum alpha-fetoprotein. Int Surg. 1984;69:361-4.

132. Klimstra DS, Heffess CS, Oertel JE, Rosai J. Acinar cell carcinoma of the pancreas. A clinicopathologic study of 28 cases. Am J Surg Pathol. 1992;16:815-37.

133. La Rosa S, Franzi F, Marchet S, Finzi G, Clerici M, Vigetti D, et al. The monoclonal anti-BCL10 antibody (clone 331.1) is a sensitive and specific marker of pancreatic acinar cell carcinoma and pancreatic metaplasia. Virchows Arch. 2009:454:133-42.

134. Hosoda W, Sasaki E, Murakami Y, Yamao K, Shimizu Y, Yatabe Y. BCL10 as a useful marker for pancreatic acinar cell carcinoma, especially using endoscopic ultrasound cytology specimens. Pathol Int. 2013;63:176-82.

135. Yasumoto M, Hamabashiri M, Akiba J, Ogasawara S, Naito Y, Taira T, et al. The utility of a novel antibody in the pathological diagnosis of pancreatic acinar cell carcinoma. J Clin Pathol. 2012:65:327-32.

136. Abraham SC, Wu T-T, Hruban RH, Lee J-H, Yeo CJ, Conlon K, et al. Genetic and immunohistochemical analysis of pancreatic acinar cell carcinoma: frequent allelic loss on chromosome $11 \mathrm{p}$ and alterations in the APC/betacatenin pathway. Am J Pathol. 2002;160:953-62.

137. Jiao Y, Yonescu R, Offerhaus GJA, Klimstra DS, Maitra A, Eshleman JR, et al Whole-exome sequencing of pancreatic neoplasms with acinar differentiation. J Pathol. 2014;232:428-35.

138. Rigaud G, Moore PS, Zamboni G, Orlandini S, Taruscio D, Paradisi S, et al. Allelotype of pancreatic acinar cell carcinoma. Int J Cancer. 2000;88:772-7.

139. La Rosa S, Sessa F, Capella C. Acinar cell carcinoma of the pancreas: overview of clinicopathologic features and insights into the molecular pathology. Front Med (Lausanne). 2015;2:41.

140. Dewald GW, Smyrk TC, Thorland EC, McWilliams RR, Van Dyke DL, Keefe JG, et al. Fluorescence in situ hybridization to visualize genetic abnormalities in interphase cells of acinar cell carcinoma, ductal adenocarcinoma, and islet cell carcinoma of the pancreas. Mayo Clin Proc. 2009;84:801-10.

141. Chmielecki J, Hutchinson KE, Frampton GM, Chalmers ZR, Johnson A, Shi C, et al. Comprehensive genomic profiling of pancreatic acinar cell carcinomas identifies recurrent RAF fusions and frequent inactivation of DNA repair genes. Cancer Discov. 2014;4:1398-405.

142. Furlan D, Sahnane N, Bernasconi B, Frattini M, Tibiletti MG, Molinari F, et al. APC alterations are frequently involved in the pathogenesis of acinar cell carcinoma of the pancreas, mainly through gene loss and promoter hypermethylation. Virchows Arch. 2014:464:553-64.

143. Guo M, Jia Y, Yu Z, House MG, Esteller M, Brock MV, et al. Epigenetic changes associated with neoplasms of the exocrine and endocrine pancreas. Discov Med. 2014;17:67-73.

144. Dhebri AR, Connor S, Campbell F, Ghaneh P, Sutton R, Neoptolemos JP. Diagnosis, treatment and outcome of pancreatoblastoma. Pancreatology. 2004:4:441-51. discussion 452-3.
145. Salman B, Brat G, Yoon Y-S, Hruban RH, Singhi AD, Fishman EK, et al. The diagnosis and surgical treatment of pancreatoblastoma in adults: a case series and review of the literature. J Gastrointest Surg. 2013;17:2153-61.

146. Weksberg R, Shuman C, Beckwith JB. Beckwith-Wiedemann syndrome. Eur J Hum Genet. 2010;18:8-14.

147. Abraham SC, Wu TT, Klimstra DS, Finn LS, Lee JH, Yeo CJ, et al. Distinctive molecular genetic alterations in sporadic and familial adenomatous polyposisassociated pancreatoblastomas : frequent alterations in the APC/beta-catenin pathway and chromosome 11p. Am J Pathol. 2001;159:1619-27.

148. Maher ER, Reik W. Beckwith-Wiedemann syndrome: imprinting in clusters revisited. J Clin Invest. 2000;105:247-52.

149. Wong IHN, Chan J, Wong J, Tam PKH. Ubiquitous aberrant RASSF1A promoter methylation in childhood neoplasia. Clin Cancer Res. 2004;10:994-1002.

150. Honda S, Okada T, Miyagi H, Minato M, Suzuki H, Taketomi A. Spontaneous rupture of an advanced pancreatoblastoma: aberrant RASSF1A methylation and CTNNB1 mutation as molecular genetic markers. J Pediatr Surg. 2013;48:e29-32.

151. Ghiorzo P. Genetic predisposition to pancreatic cancer. World J Gastroenterol. 2014;20:10778-89.

\section{Submit your next manuscript to BioMed Central and we will help you at every step:}

- We accept pre-submission inquiries

- Our selector tool helps you to find the most relevant journal

- We provide round the clock customer support

- Convenient online submission

- Thorough peer review

- Inclusion in PubMed and all major indexing services

- Maximum visibility for your research

Submit your manuscript at www.biomedcentral.com/submit
) Biomed Central 